ANGELIKA MODLIŃSKA-PIEKARZ* - LUBLIN

\title{
SIEDEMNASTOWIECZNA SYLWA W ZBIORACH BIBLIOTEKI UNIWERSYTECKIEJ KUL
}

W zbiorach rękopiśmiennych Biblioteki Uniwersyteckiej KUL pod sygnaturą 2629 inwentarza ogólnego rękopisów znajduje się siedemnastowieczny kodeks rękopiśmienny z kopiami listów, mów, poezji i różnorakiego piśmiennictwa historycznego. Rękopis to typowa siedemnastowieczna silva rerum zawierająca kopie listów królów, magnatów i innych dostojników państwowych oraz ludzi biorących czynny udział w życiu politycznym Rzeczypospolitej w okresie panowania trzech królów z rodziny Wazów: Zygmunta III, Władysława IV i Jana Kazimierza. Ponadto znajdują się tu również przemówienia polityczne, akta traktatów pokojowych, mowy obrzędowe i okolicznościowe, okolicznościowa twórczość poetycka taka jak panegiryki, epitafia, lamentacje, epigramaty, utwory o charakterze politycznym i dworskim napisane w języku polskim i łacińskim, tylko jeden tekst napisany jest w języku niemieckim.

\section{Opis fizyczny}

Rękopis ma wymiary 30,5 x 21,5 cm, oprawa jest miękka, stanowi ją kilka kartek sklejonych razem (są to karty siedemnastowiecznych pruskich kalendarzy drukowanych), pokrytych znacznie pofałdowanym, zielonym pergaminem, który w wielu miejscach stracił już swoją barwę. Kodeks zawiera 319 kart zszytych razem, z których karty 7 do 178 posiadają oryginalną paginację sporządzoną przez jednego z kopistów s. 1-354=k. 7-178. Cały kodeks liczył kiedyś 43 składki, wszystkie składki zawierały cztery arkusze złożone $\mathrm{z}$ ośmiu kart w formacie in folio. Aktualnie zachowały się 42 kwaterniony z pewnymi brakami.

Tak przedstawia się stan i charakter składek:

* Angelika Modlińska-Piekarz - dr neolatynistyki, starszy bibliotekarz w Sekcji Rękopisów Biblioteki Uniwersyteckiej KUL. 
1. k. 1-6 (brak dwóch pierwszych kart zawierających spis treści sylwy); teksty przepisywał pierwszy kopista, składka została dodana później jako spis treści, następnie dopisano tekst na kartach 5-6, który powinien się znajdować w okolicach składki dwudziestej czwartej; filigran z dwoma wężami w koronach i inicjałami MB na bokach ${ }^{1}$.

2. k. 7-14 = według dawnej paginacji s. 1-16; przepisywał kaligraficznie pierwszy kopista; filigran z krzyżem z podwójnym ramieniem ${ }^{2}$.

3. k. $15-22$ = s. 17-32; pierwszy kopista kaligraficznie; filigran z krzyżem, jak wyżej.

4. k. $23-30=$ s. 33-48; pierwszy kopista kaligraficznie; filigran z krzyżem, jak wyżej.

5. k. 31-38 = s. 49-64; pierwszy kopista kaligraficznie; filigran z herbem topór ${ }^{3}$.

6. k. 39-44 = s. 65-80 (brak 2 kart, s. 67-70); pierwszy kopista kaligraficznie do s. 79 (góra strony), pierwszy kopista nieco innym duktem, w późniejszym okresie od s. 79 (dół strony); filigran z krzyżem, jak wyżej.

7. k. 45-52 = s. 81-96; pierwszy kopista; filigran z dwoma wężami, jak wyżej.

8. k. 53-60 = s. 97-112; pierwszy kopista; filigran z dwoma wężami, jak wyżej.

9. k. 61-68 = s. 113-128; pierwszy kopista; filigran z dwoma wężami, jak wyżej.

10. k. $69-76=$ s. $129-144$; pierwszy kopista; filigran z lilijką .

11. k. $77-84=$ s. 145-160; pierwszy kopista; filigran z lilijka, jak wyżej.

12. k. $85-92$ = s. 161-17; pierwszy kopista; filigran z lilijka, jak wyżej.

13. k. $93-100=$ s. $178-193$ (pomyłka w numeracji, brak strony 177); pierwszy kopista; filigran z lilijka, jak wyżej.

14. k. 101-108 = s. 194-209; pierwszy kopista; filigran z lilijka, jak wyżej.

15. k. $109-116=$ s. $210-225$; pierwszy kopista; filigran z lilijka, jak wyżej.

16. k. $117-124=$ s. 226-241; pierwszy kopista; filigran z lilijka, jak wyżej.

17. k. $125-132$ = s. $242-257$; pierwszy kopista, na s. 253 tekst urwany, s. 254 pusta; filigran okragły z orłem $\mathrm{w}$ środku ${ }^{5}$.

18. k. $133-140=$ s. $258-273$; pierwszy kopista, filigran z dwoma wężami, jak wyżej.

19. k. $141-145=$ s. $274-289$ (brak 3 kart s. 278-283); pierwszy kopista, filigran z dwoma wężami,

20. k. $146-153$ = s. 290-305; pierwszy kopista; filigran z dwoma wężami, jak wyżej.

\footnotetext{
${ }^{1}$ Zob. E. Laucevicius, Popierius Lietuvoje XV-XVIII a, Vilnius 1967, filigran nr 926. Takimi filigranami sygnowano papier w Brześciu Litewskim 1649, Wilnie 1652 i Kownie 1653.

${ }^{2}$ Według J. Siniarskiej-Czaplickiej jest to herb Duchaków z papierni Drohiczyna z 1651 lub Krakowa 1654. Zob J. Siniarska-Czaplicka, Filigrany papierni położonych na obszarze Rzeczypospolitej Polskiej od poczatku XVI wieku do połowy XVIII wieku, Wrocław-Warszawa 1969, filigran nr 158 (Drohiczyn 1651), filigran nr 159 (Kraków 1654). Tutaj bardziej prawdopodobne wydaje się ustalenie E. Lauceviciusa, podające papiernię wileńską z 1655 roku. Zob. Laucevicius, Popierius Lietuvoje, filigran nr 1795 (Wilno 1655).

${ }^{3}$ Siniarska-Czaplicka, Filigrany, filigran nr 1123 (Kraków 1649).

${ }^{4}$ Laucevicius, Popierius Lietuvoje, filigran nr 2165, ale bez inicjałów (Rasienie 1639).

${ }^{5}$ Tamże, filigran $\mathrm{nr} 141$ (Rasienie 1646).
} 
21. k. 154-161 = s. 306-321; pierwszy kopista; filigran z dwoma wężami, jak wyżej.

22. k. $162-169=$ s. 322-337; pierwszy kopista; filigran z dwoma wężami, jak wyżej.

23. k. $170-177=$ s. 338-353; pierwszy kopista, filigran z dwoma wężami, jak wyżej.

24. k. 178-185 (k. 178 r. = s. 354; jest to ostatnia strona dawnej paginacji); pierwszy kopista do k. 183 r. (góra strony), drugi kopista kursywą od k. 183 r. (dół strony), trzeci kopista kaligraficznie od k. 183 v. do k. 184 r., następnie ponownie kopista drugi do k. 185 v. (góra strony), czwarty kopista od s. 185 v. (dół strony); filigran z dwoma wężami, jak wyżej.

25. k. 186 -193; czwarty kopista do k. 188 r. (góra strony), drugi kopista kursywą k. 188 r. (dół strony) do k. 189 r. (góra strony), czwarty kopista k. 189 r. (dół strony) do k. 190 r.(góra strony), drugi kopista k. 190 r. (dół strony) do k. 191 r. (góra strony), czwarty kopista k. 191 r. (dół strony) do k. 192 v. (góra strony), trzeci kopista kaligraficznie od s. 192 v. (dół strony); filigran jak wyżej.

26. k. 194-201; trzeci kopista kaligraficznie; filigran jak wyżej.

27. k. 202-209; trzeci kopista kaligraficznie; filigran jak wyżej.

28. k.210-218; trzeci kopista kaligraficznie; filigran jak wyżej.

29. k. 219-226; trzeci kopista kaligraficznie; filigran jak wyżej.

30. k. 227-234; trzeci kopista kaligraficznie; filigran jak wyżej.

31. k. 235-237 (brak pięciu kart); trzeci kopista kaligraficznie; filigran jak wyżej.

32. k. 238-240 (brak pięciu kart);trzeci kopista kaligraficznie; filigran jak wyżej.

33. k. 241-248; trzeci kopista kaligraficznie do k. 248 r. (góra strony), dalej kopista drugi kursywa; filigran jak wyżej.

34. k. 249-256; drugi kopista kursywą; filigran jak wyżej.

35. k. 257-264; drugi kopista kursywą; filigran jak wyżej.

36. k. 265-272; drugi kopista kursywą; filigran jak wyżej.

37. k. 273-281; drugi kopista kursywą; filigran jak wyżej.

38. k. 282-289; drugi kopista kursywą; filigran jak wyżej.

39. k. 290-297; drugi kopista kursywą; filigran jak wyżej.

40. k. 298-305; drugi kopista kursywą; filigran jak wyżej.

41. k. 306-313; drugi kopista kursywą do k. 310 v. (góra strony, trzeci kopista kaligraficznie od k. $310 \mathrm{v}$. (dół strony) do k. 312 r. (góra strony), dalej drugi kopista; filigran jak wyżej.

42. k. 314-319 (brak dwóch kart); drugi kopista kursywą do k. 315 r., od dołu tej strony kopista piąty; filigran jak wyżej.

43. składka w całości wyrwana.

Z pierwszej składki zostały wydarte dwie karty z początkiem spisu treści księgi sporządzonego przez pierwszego kopistę. $Z$ zachowanego fragmentu widać, że pierwszy kopista podzielił zawarte w niej materiały na kilka działów: miscellanea (teksty polityczno-wyznaniowe), (utwory) weselne, pogrzebne oraz epitafia, przydzielając im odrębne rubryki. Prawdopodobnie spis sporządzony był w całości, niestety karty z opisem stron 1-270 zostały później przez kogoś wyrwane. Na zachowanej karcie wypełniona jest tylko rubryka miscellanea obejmująca zawartość 
stron 270 do 354 według siedemnastowiecznej paginacji, pozostałe rubryki sa puste. Spis ten przedstawia się w następujący sposób:

Pemptas prima ad Martinum Gratianum, p. 271

Secunda Domini Jacobi Wujek sub nomine Sereniss. Pol. Regis et Reginae, p. 272.

Tertia, ibidem.

Quarta, ibidem.

Quinta epigramma ad Martinum Gratianum, p. 273.

In divum Hallensem Lipsii, p. 276.

De Polonia vaticinium, p. 276.

Albo inscriptum Dn. H., ibidem.

Albo Stephani Benjamini Sziylaga Gerardo Vossio Amserdam. inscriptum, $p$. 277.

Ad Reginam Pol. et Sueciae, ibidem.

Rycerstwo Jezuickie, ibidem.

Oratio Papistarum, p. 279.

Salutatio Antichristi, ibidem.

Genesis filii perditionis, ibidem.

Instructia jakby się bronić miat Ewangelik temu, któryby go w wierze nawatlić chciat, p. 280.

Pieśn, p. 284.

Oratio genethalica Polonica, p. 285.

List Radziejowskiego do Chmielnickiego, p. 296.

Tegoż list do Wyhowskiego, p. 299.

It. Manifestatio innocentiae eius, $p$. 300.

Literae Regis Wladislai IV ad Portam Ottomanicam, p. 310.

Joannis Skytte Leg. Suec. Orat. ad Reg. Angl. Tres, p. 315.

Zachowany fragment spisu treści pozwala dziś odtworzyć zawartość trzech wyrwanych kart (s. 278-283 według dawnej paginacji). Brak jest dalszego ciagu utworu pt. Rycerstwo Jezuickie w Poznaniu 1596 tekst początkowy został skreślony (jest to s. 277 dawnej paginacji, w nowej foliacji k. 142 v.), utwór ten obejmował jeszcze całą kolejną stronę dawnej paginacji, brakuje też Oratio Papistarum, Salutatio Antichristi, Genesis filii perditionis, Instructia jakby się bronić miat Ewangelik temu, któryby go w wierze nawatlić chciat. Niewątpliwie zostały one wyrwane z powodu ich antykatolickiej treści, prawdopodobnie późniejszy właściciel księgi miał obawy trzymać w swoim domu teksty o charakterze jawnie antykatolickim, a że chciał zachować zawartość sylwy, usunął tylko te najbardziej obraźliwe paszkwile, być może ta sama osoba zniszczyła również spis treści, by nie było widać, jaką treść zawiera rękopis. 


\section{Twórcy}

Trudno z całą pewnością stwierdzić, w jakim czasie powstał rękopis. Z pewnością teksty były pisane na przestrzeni co najmniej kilkunastu, a może nawet przeszło dwudziestu lat przez pięć osób. Biorąc pod uwagę datę produkcji (16491655) i pochodzenie papieru (dostarczono go $\mathrm{z}$ terenów Wielkiego Księstwa Litewskiego (z Wilna, Brześcia Litewskiego, Rasienia), część może z Podlasia (Drohiczyna), przepisywanie księgi rozpoczęto po roku 1655. Pierwszy kopista zaczął więc przepisywać teksty $\mathrm{w}$ drugiej połowie lat pięćdziesiątych, pisał je przypuszczalnie przez kilka, a może nawet kilkanaście lat, zapewne z przerwami i w różnych miejscach, różnym piórem i inkaustem, dlatego dukt jego pisma jest zmienny, widać jednak, ze teksty do k. 183 r. napisane są tą samą ręką. Dodatkową pomocą dla przybliżenia osoby pierwszego kopisty jest notatka napisana na karcie pierwszej ołówkiem pismem dziewiętnastowiecznym (ewentualnie z początku dwudziestego wieku): „...Mięszaniny z czasów trzech królów rodziny szwedzkiej. Sa i ariańskie rzeczy. Mp [manuskrypt] byt napisat jakiś arianin”. Dalej wyraźniej tym samym pismem: ,Mięszaniny z czasów trzech królów z rodziny Wazów (Sq i ariańskie rzeczy)". Uwagi poczynione przez nieznanego bliżej badacza są niewątpliwie słuszne, wszystko bowiem wskazuje, że pierwszy kopista był arianinem lub działaczem protestanckim blisko związanym z kręgiem ariańskim i kalwińskim. Księgę rozpoczynała wszakże „Uniżona prośba do króla Jego Mości Pana Naszego Miłościwego y Stanów Rzplitej na Seym Walny Warszawski roku 1627 w sprawie Dissidentium in religione w uciskach ich pisana", następnie przedstawiono krótką rozprawkę „Przyczyny dla których Ich. Mści PP Dyssidentes a Religione Catholica lubo miedzy sobq różni, jedni drugich odstęować nie maja, alie radziey communem spólna zgoda i pomoca popierać powinni", jest również tekst w obronie Braci Polskich: Rationes cur Ecclesiae Romanae antistites atque cives non adeo deberent esse infensi Fratribus Polonis, quos vulgo Arianos quanquam iniuria vocant, sq mowy znanych działaczy ariańskich takich jak Samuel Przypkowski czy Andrzej Moskorzewski oraz kalwińskich jak Piotr Kochlewski. Protestancki (choć niekoniecznie ariański) charakter sylwy potwierdza także fakt, że zawiera ona dużo paszkwili na katolików, którzy w spisie treści zostali określeni mianem papistae”, a takie określenie jest, jak wiadomo, charakterystyczne dla pism protestanckich. Część sylwy przez niego przepisana zawiera treści polityczne nawiązujące do polemiki religijnej z katolikami i do szeroko rozumianej walki z opozycja katolicka. Prawdopodobnie początkowe teksty pisano na terenie Rzeczypospolitej, a późniejsze sporządzono w Prusach Książęcych. Gdyby tak było w istocie, że księgę początkowo pisano na terenie Wielkiego Księstwa Litewskiego lub Podlasia (stąd pochodzi papier), a później w Prusach Książęcych (karty okładzinowe wewnątrz oprawy pergaminowej to fragmenty pruskich kalendarzy, z których jeden zawiera datę: $1641 \mathrm{r}$.), potwierdzałoby się przypuszczenie, że kopista wywodził się z kręgu arian, którzy w roku 1658 zostali skazani na wygnanie i wielu z nich osiedliło się w Prusach, pozostając pod kuratelą księcia Bogusława Radziwiłła. Drugi, czwarty i piąty kopista (udział czwartego i piątego jest tu znikomy) kontynuują antykatolicki charakter zapisków. 
Ich teksty pisane były głównie po łacinie, tekstów polskich jest niewiele, preferowano wypisy z autorów z Europy Zachodniej, dużo jest tu poezji okolicznościowej w języku łacińskim, takiej jak epitafia, epigramaty, panegiryki, paszkwile. Inny charakter mają zaś zapiski trzeciego kopisty, który z pewnością jest Polakiem (pisze tylko po polsku) i przepisuje dokumenty dotyczące domu radziwiłłowskiego, zwłaszcza z okresu działalności Krzysztofa Radziwiłła jako hetmana polnego litewskiego, przeważnie z lat 1628-1635, prawdopodobnie ów kopista lub ktoś $\mathrm{z}$ kręgu jego znajomych $\mathrm{w}$ tym czasie pozostawał u hetmana na służbie. Wpisy dokonane przez drugiego, trzeciego i czwartego kopistę musiały niewattpliwie poprzedzić wpisy piątego kopisty, który przepisywał teksty na kilku końcowych (spośród tych, które się zachowały) kartach kodeksu i uczynił to, jak się wydaje, w pierwszej połowie lat siedemdziesiątych XVII wieku, na co wskazuje jego adnotacja na karcie 314 verso, na marginesie epigramatu poświęconego Karolowi IV Lotaryńskiemu, gdzie informuje czytelnika, że jest to pozorne epitafium, gdyż książę Lotaryngii żyje jeszcze i jest w niewoli. Karol IV Lotaryński przebywał w niewoli francuskiej w ostatnich latach swego życia, to jest okresie 1670-1675. Dodać należy, że dwa utwory poświecone księciu Lotaryngii znajdujące się na końcu kodeksu stanowią wyjątek wśród przepisywanych dokumentów, gdyż większość opisywanych zdarzeń dotyczy zdarzeń od początku siedemnastego stulecia do 1654 roku włącznie, niektóre tylko dotyczą wydarzeń wcześniejszych, jak ścięcie Samuela Zborowskiego czy rokosz Zebrzydowskiego. Najwięcej tekstów odnosi się do wydarzeń z czasów panowania Władysława IV, nieco mniej z czasów Jana Kazimierza, najmniej z okresu panowania Zygmunta III Wazy.

\section{Proweniencja}

Do 2003 roku rękopis pozostawał w nieopracowanych zbiorach rękopisów Biblioteki Uniwersyteckiej KUL, autorka niniejszego artykułu znalazła go wśród innych siedemnasto i osiemnastowiecznych ksiagg pozostających w starych zasobach rękopiśmiennych biblioteki. W jaki sposób się tutaj znalazł, trudno dziś stwierdzić. Nie ulega natomiast watpliwości, skąd pochodzi. Podpowiedziała to już osoba, która na pierwszej stronie kodeksu sporządziła ołówkiem wspomnianą wyżej notatkę, u góry napisano wyraźnie: „1635. Rękopism Archiwum Korczewskiego". Pochodzenie rękopisu potwierdza jednak przede wszystkim przyklejony na wewnętrznej stronie oprawy ekslibris i pieczęć tuszowa odbita na pierwszej, drugiej i przedostatniej stronie rękopisu. Na kunsztownie wykonanym ekslibrisie widnieje herb Rawicz (dziewica siedząca na niedźwiedziu) z umieszczoną u dołu dewizą: „Korczew. Z Bogiem nad Bugiem”. Zarówno herb jak i dewiza należy do rodziny Ostrowskich, ostatnich właścicieli Korczewa. Te samo zawołanie, herb Rawicz oraz inicjały A. F. R.O. znajdują się na pieczęci tuszowej. Są to bez wątpienia inicjały jednego z właścicieli Korczewa - Aleksandra Feliksa hrabiego Rawity-Ostrowskiego herbu Rawicz. Idąc tym tropem można domyślać się, do kogo mógł należeć rękopis w osiemnastym, dziewiętnastym i dwudziestym wieku. Przypuszczalnie rękopis mógł mieć w swym posiadaniu już Wiktoryn Kuczyński, 
kasztelan podlaski, który kupił Korczew w 1712 roku, a w 1734 roku zbudował tam pałac zaprojektowany przez architekta nadwornego Radziwiłłów Konceniego Boni i zorganizował bibliotekę, w której zgromadzono książki i dokumenty głównie po Kuczyńskich. Jest wysoce prawdopodobne, że omawiana tutaj sylwa była w pałacu korczewskim od początku istnienia biblioteki, musiała zatem przechodzić w ręce kolejnych właścicieli Korczewa, a więc kolejno w ręce Leona Kuczyńskiego, konfederata barskiego, jego syna Feliksa, a następnie Aleksandra Kuczyńskiego, na którym wygasła linia męska Kuczyńskich. Po nich dobra korczewskie, a więc i ten rękopis, przejęła córka Aleksandra i Joanny Kuczyńskich, Ludwika Kuczyńska wydana za Tadeusza Ostrowskiego. Po Ludwice Kuczyńskiej, kolejnym właścicielem Korczewa został jej syn, Aleksander Ostrowski, właściciel wspomnianego wyżej ekslibrisu. Wiadomo, że tym właśnie ekslibrisem była oznaczona nie tylko omawiana tutaj sylwa, lecz wszystkie książki znajdujące się w bibliotece pałacu korczewskiego. Zgromadzono w niej setki książek, a także szereg rękopisów i dokumentów, w tym listy, które napisał Cyprian Kamil Norwid do „Pani na Korczewie”, czyli do Joanny Kuczyńskiej, matki Ludwiki Ostrowskiej. Dziedzicem Aleksandra Ostrowskiego i zarazem ostatnim przedwojennym właścicielem biblioteki był zaś Krystyn Ostrowski (zmarły na emigracji w Wielkiej Brytanii w 1980 r.) oraz jego córki: Renata Ostrowska (zm. w 2002) i żyjąca do dziś Beata Ostrowka-Harris, które choć utraciły w czasie wojny cały majątek rodzinny, zdołały jednak szczęśliwie odzyskać pałac w Korczewie w 1990 roku, odkupiwszy go od skarbu państwa za symboliczną złotówkę. Niestety nigdy nie odzyskały cennej biblioteki, gdyż w czasie II wojny światowej Niemcy spalili na dziedzińcu niemalże wszystkie książki i rękopisy zgromadzone w pałacu korczewskim. Tak więc sylwa znajdująca się w zbiorach Biblioteki KUL należy do jednych z nielicznych, które ocalały. Jak to się stało, że się zachowała? Nie wiadomo. Można przypuszczać, że w czasie wojennej zawieruchy została skradziona z pałacu, podobnie jak część listów Norwida do Kuczyńskiej ${ }^{6}$, które później zostały sprzedane Bolesławowi Piaseckiemu. Piasecki podarował listy Norwida Bibliotece Narodowej w Warszawie. Prawdopodobnie i nasz rękopis został po wojnie przez kogoś kupiony, a następnie podarowany lub sprzedany Bibliotece KUL. Niestety nie ma w kodeksie żadnych adnotacji ani o darze, ani o kupnie. Mimo braku pewnych dowodów, w toku pracy nad kodeksem wysnułam hipotezę, że ofiarodawcą sylwy mógł być znany badacz i bibliofil ks. Ignacy Wierobiej, proboszcz Hajnówki, który w 1970 roku przekazał Bibliotece KUL ogromny księgozbiór i liczne rękopisy i materiały historyczne. Być może wraz z jego notatkami przywieziono także ten kodeks. Skąd takie przypuszczenie? Niewątpliwie znaczą-

${ }^{6}$ Listy i wiersze, które napisał Cyprian Kamil Norwid do Kuczyńskiej, były przechowywane do XX wieku w pałacu w Korczewie. W latach 1916-1918 część z odnalezionych listów została ogłoszona drukiem. Kolejna część wiosną 1939 r. została przewieziona do warszawskiego mieszkania hrabiów Ostrowskich z myślą utworzenia tam archiwum. Jednak już we wrześniu 1939 r., na skutek bombardowań listy spłonęły. Trzecia, a zarazem ostatnia część norwidianów, została w czasie drugiej wojny św. skradziona z pałacu, sprzedana Bolesławowi Piaseckiemu - przewodniczącemu PAX i w 1963 r. opublikowana. Obecnie listy Norwida do Pani na Korczewie znajdują się w Bibliotece Narodowej w Warszawie. 
cym tropem do zbadania historii sylwy jest krótka notatka napisana zieloną kredką na karcie 33 recto: „,w Rzemianowicach” oraz na marginesie: „(por. Pułaski, Opis rękopisów...., s. 430)". Osoba, która zostawiła tę uwagę musiała porównywać kodeks z książką Franciszka Pułaskiego Opis 815 rękopisów Biblioteki Ordynacji Krasińskich, opublikowaną w Warszawie 19157. Na wskazanej przez autora notatki stronie 430 jest podany opis rękopisu o sygn. 290, który Franciszek Pułaski zidentyfikował jako „Miscellanea historyczne z lat 1592-1713, zbiór mów przeważnie Andrzeja Moskorzewskiego"8. Autor notatki musiał więc mieć kodeks w rękach po roku 1915, to jest po wydaniu inwentarza Franciszka Pułaskiego. Trudno z całą pewnością twierdzić, kto był autorem ,zielonej” notki, ale nasuwa się przypuszczenie, że mógł nim być ks. Ignacy Wierobiej, gdyż miał podobny charakter pisma i podobny zwyczaj dopisywania ważnych spostrzeżeń kolorowymi kredkami. Podobnym pismem i również zieloną kredka zapisana jest karta okładzinowa pochodzącej z jego księgozbioru książki Kazimierza Bartoszewicza pt. Radziwiłłowie. Co ciekawe, podobne notki bibliograficzne odnoszące się do czytanego materiału bardzo często występują w materiałach rękopiśmiennych ks. Ignacego Wierobieja przechowywanych w Bibliotece KUL i niejednokrotnie cytowana była tam właśnie publikacja Franciszka Pułaskiego. Niestety hipoteza, że to ks. Ignacy Wierobiej sporządził ową notatkę, jest obecnie raczej niemożliwa do sprawdzenia, pewne jest jednak, że jej autor był badaczem dobrze obznajomionym ze źródłami historycznymi i czytał kodeks stosunkowo niedawno, bo na pewno po roku 1915. Mogło być i tak, że ten nieznany badacz jeszcze w okresie międzywojennym wypożyczył rękopis od Ostrowskich, co skutkowało tym, że w czasie wojny był on poza Korczewem i dlatego ocalał. Tego się już prawdopodobnie nigdy nie dowiemy. Droga autorstwa, własności i losów sylwy kryć będzie jeszcze długo wiele tajemnic. Mimo to, jej wartość historyczna jest bezsprzeczna, każda tego typu sylwa jest wszakże unikatem, każdy tekst, choćby powtarzał się w innych rękopisach, różni od innych odpisem, a często i ważnymi dla historyka szczegółami. Rękopis korczewski jest niewątpliwie cenny przede wszystkim ze względu na zagadnienia dotyczące działaczy ariańskich i kalwińskich oraz liczne dokumenty życia i działalności Radziwiłłów birżańskich. Wydaje się więc, że posiadając znaczną liczbę tekstów niepublikowanych nigdzie indziej może wnieść wiele nowych, istotnych szczegółów dla zainteresowanych historią polityczną i literacką siedemnastego stulecia.

\footnotetext{
${ }^{7}$ F. Pułaski, Opis 815 rękopisów Biblioteki Ordynacyi Krasińskich, Warszawa 1915.

${ }^{8}$ Tamże, s. 426-433.
} 


\section{Inwentarz zawartości księgi}

Zawartość rękopisu w całości przedstawia się następująco:

1. Podkanclerzy koronny Hieronim Radziejowski do rady koronnej, 23 I 1652 r. ${ }^{9}$, k. 5 r.

2. Wojewoda poznański do króla Jana Kazimierza, Rzeczyce 16 I $1652^{10}$, k. 5v6r.3.

3. Bohdan Chmielnicki, hetman wojska zaporowskiego do wójtów, burmistrzów, rajców i mieszczan Kamieńca Podolskiego, 17 VI 1652 ${ }^{11}$, k. 6 r.

4. Regimentarze i Starsi Miasta Kamieńca Podolskiego do Bohdana Chmielnickiego, Kamieniec 17 VI $1652^{12}$, k. 6r-6v.

5. Uniżona prośba do króla Pana Naszego Miłościwego y Stanów Rzplitej na Seym Walny Warszawski roku $1627 \mathrm{w}$ sprawie Dissidentium in religione w uciskach ich pisana ${ }^{13}$, k. 7 r.-14 r.

6. Przyczyny dla których Dyssidentes a Religione Catholica lubo miedzy sobą różni, jedni drugich odstępować nie mają, alie radziey communem spólną zgodą i pomocą popierać powinni ${ }^{14}, \mathrm{k} .14 \mathrm{v}-15 \mathrm{r}$.

${ }^{9}$ List Hieronima Radziejowskiego z dnia 23 I 1652 z prośbą o uniewinnienie od stawianych mu zarzutów zdrady stanu.

${ }^{10}$ List Krzysztofa Opalińskiego, wojewody poznańskiego do króla Jana Kazimierza, Rzeczyce 16 I 1652.

${ }^{11}$ List Bohdana Chmielnickiego do wójtów, burmistrzów, rajców i mieszczan Kamieńca Podolskiego z dnia 17 VI 1652 roku, to jest podczas oblężenia Kamieńca Podolskiego przez wojska Chmielnickiego, w wkrótce po odniesionym przez niego zwycięstwie nad wojskami koronnymi pod Batohem 2 VI $1652 \mathrm{r}$.

${ }^{12}$ Odpowiedź z dnia 17 VI 1652 regimentarzy i starszych miasta Kamieńca Podolskiego na powyższy list Bohdana Chmielnickiego.

${ }^{13}$ Memoriał różnowierców na sejmie walnym warszawskim jesienią 1627 roku, w którym ostro skrytykowano wyrok na kalwiniście Samuelu Bolestraszyckim i domagano się kasaty wszystkich postanowień Trybunału Koronnego z 1627 r. niekorzystnych dla dysydentów. Uwaga: Józef Łukaszewicz mylnie przypisuje tę mowę Krzysztofowi Radziwiłłowi, który nie brał w ogóle udziału w sejmie warszawskim, a relację z wydarzeń sejmowych przekazał mu Samuel Przypkowski, gorliwy działacz ariański. Mowa błędnie publikowana jako radziwiłłowska, brzmi bardzo podobnie jak w naszym kodeksie, choć widać, że usunięto z niej dużo makaronizmów łacińskich. Treść mowy ma mocny koloryt walki wyznaniowej, dobitnie mówi o prześladowaniach dysydentów. Por. J. Łukaszewicz, Dzieje kościołów wyznania helweckiego w Litwie, Poznań 1842, t. 1, s. 170-179; Por. także mowę Krzysztofa Radziwiłła na sejmiku nowogródzkim opublikowaną w: Księcia Krzysztofa Radziwiłla hetmana polnego Wielkiego Księstwa Litewskiego sprawy wojenne i polityczne 1621-1632, Paryż 1859, s. 573-577; Zob. także odniesienie do tych źródeł: H. Merczyng, Druga w Polsce egzekucja literacka, „Przegląd Historyczny”, 17 (1913), s. 67-74 oraz recenzja powyższego: J. W. Opatrny, „Kwartalnik Historyczny”, 34 (1920), s. 139-148; L. Chmaj, Samuel Przypkowski na tle pradów religijnych XVII wieku, Kraków 1927, s. 15-19; Z. Trawicka, Działalność polityczna i reformacyjna Piotra Kochlewskiego, „Odrodzenie i Reformacja w Polsce”, 8 (1963), s. 147. Tę samą mowę zawiera kodeks nr 102 Biblioteki Jagiellońskiej.

${ }^{14}$ Prawdopodobnie także jest to mowa wygłoszona na tym samym sejmie warszawskim z 1627 
7. Mowa Pana Andrzeja Moskorzowskiego na pogrzebie Paniey Jadwigy z Bembelna Chrząstowskiej od potomków jej 1632r. ${ }^{15}$, k. 16r-16v.

8. Mowa Pana krayaczego koronnego na pogrzebie księcia Pana Krakowskiego ${ }^{16}$, k. 16 v-19r.

9. Przemowa pogrzebna Piotra Kochlewskiego na pogrzebie Pana Kosakowskiego, sługi Xcia Pana Hetmana W.K.L. ${ }^{17}$, k. 19 r-20r.

10. Rzec Pana Jakuba Sobieskiego, starosty krasnostawskiego na pogrzebie świętej pamięci Wielkiego Kawalera w Warszawie u świętego Jana w kaplicy Świętokrajskiej proboszcza warszawskiego nazwany pochowanego pod czas sejmowy, w Roku Pańskim 1625 dnia 10 lutego ${ }^{18}$, k. 20 r -21r.

11. Mowa Pana wojewodzica bełskiego na pogrzebie Xcia Pruńskiego ${ }^{19}$, k. 21 r$21 \mathrm{v}$.

12. Mowa Pana Andrzeja Moskorzowskiego na pogrzebie Pana Krzysztopha Morsztyna starosty philipowskiego, $1642^{20}, \mathrm{k} .21 \mathrm{v}-23 \mathrm{v}$.

13. Przedmowa Pana Jerzego z Tęczyna Ossolińskiego podstolego koronnego, starosty pilźnickiego na pogrzebie Pana Stanisława Cikowskiego podkomorzyca krakowskiego, we Brniu Roku $1631^{21}$, k. 23 v-24 r.

14. Replica na te mowę Pana Andrzeja Moskorzowskiego ${ }^{22}$, k. 24 r.- 25 r.

roku skierowana do senatu i izby poselskiej. Fragmenty publikuje Łukaszewicz, Dzieje kościołów, s. $179-180$.

${ }^{15}$ Mowa Andrzeja Chrystiana Moskorzowskiego, działacza sejmikowego i ariańskiego, poety i mówcy (ok. 1595-1650) wygłoszona w Rakowie 1632 roku na pogrzebie arianki Jadwigi Chrząstowskiej z Gosławskich, żony Andrzeja Chrząstowskiego z Brzezia (zmarłego przed 1632), który z kalwinizmu przeszedł na arianizm. Tę samą mowę zawierał rękopis nr 290 Biblioteki Ordynacji Krasińskich. Por. Pułaski, Opis 815 rękopisów, s. 431.

${ }^{16}$ Mowa Jakuba Sobieskiego, krajaczego koronnego na pogrzebie Jerzego Zbaraskiego, kasztelana krakowskiego z 13 X 1631 r.

${ }^{17}$ Mowa Piotra Kochlewskiego wygłoszona prawdopodobnie na pogrzebie Mikołaja Kossakowskiego zmarłego w 1639, kasztelana czernihowskiego, który brał udział w walkach ze Szwedami, Tatarami, Kozakami i w wyprawach moskiewskich. Piotr Kochlewski był kalwinistą, sługa Krzysztofa Radziwiłła, zagorzałym obrońcą interesów różnowierczych, pisał napomnienia, poezje.

${ }^{18}$ Mowa Jakuba Sobieskiego na pogrzebie Bartłomieja Nowodworskiego, współtowarzysza kampanii moskiewskiej. Polski Słownik Biograficzny podaje, że pogrzeb odbył się 18 II 1625, hasło Sobieski Jakub, w: „Polski Słownik Biograficzny”(dalej: PSB), Warszawa-Kraków 1999, t. 39 s. 485.

${ }^{19}$ Mowa Andrzeja Leszczyńskiego (1606-1651), syna wojewody bełskiego, Rafała Leszczyńskiego (1579-1636) i Anny Radzimińskiej, na pogrzebie księcia Aleksandra Oktawiana Pruńskiego (zm. 1638), przyrodniego brata matki.

${ }^{20}$ Mowa Andrzeja Moskorzowskiego wygłoszona dnia 5 X 1642 r. na pogrzebie Krzysztofa Morsztyna młodszego, gorliwego arianina, starosty filipowskiego. Moskorzowski wychwala w tej mowie zasługi zmarłego w opiece nad ubogimi i chorymi. Ta sama mowa była w rękopisie nr 290 Biblioteki Ordynacji Krasińskich. Por. Pułaski, Opis, s. 431.

${ }^{21}$ Mowa Jerzego Ossolińskiego na pogrzebie Stanisława Cikowskiego w 1631 roku. W mowie tej Jerzy Ossoliński wyraził się niefortunnie, jakoby brakowało w Rzeczypospolitej bohaterów. Ta sama mowa była w rękopisie 290 Biblioteki Ordynacji Krasińskich. Por. Pułaski, Opis, s. 430-431.

${ }^{22}$ Replika polityczno-religijna ze strony Andrzeja Moskorzowskiego na powyższą mowę Jerze- 
15. Mowa Pana Andrzeja Zborowskiego na pogrzebie Brata Jego P. Samuela, die 30 Mai o godzinie siedemnastej Anno Domini...23, k. 25 v - 27 r.

16. Dziękowanie za Pannę 24, k. 27 r - 27 v.

17. Oddawanie Panny ${ }^{25}$, k. 27 v. -28 v.

18. Dziękowanie za upominki ${ }^{26}, \mathrm{k} .28 \mathrm{v}$.

19. Dziękowanie za Pannę ${ }^{27}$, k. 28 v-29 r.

20. Dziękowanie za Pannę Grekównę od Kurosza P. Samulea Przypkowskiego ${ }^{28}$, k. 29 v. -30 v.

21. Oddawanie Panny Jadwigi Wylamowskiej Piotrowi Sieniucie w Radostowie, dnia 27 Novembris $1640^{29}$, k. $30 \mathrm{v}$.

22. Dziękowanie za Pannę starościankę brańską ${ }^{30}$, k. 32 r - 33 r.

23. Mowa Pana Andrzeja Moskorzowskiego, którą oddawał Pannę Barbarę Slichtingównę, Córkę Pana Jonasza Slichtinga z Bukowca ${ }^{31}$ Panu Łazińskiemu Władysławowi ,w Rzemianowicach $1643^{\text {”, }}{ }^{32}$, k. 33 r. - 35 r.

go Ossolińskiego. Ta sama mowa była w rękopisie 290 Biblioteki Ordynacji Krasińskich. Por. Pułaski, Opis, s. 431.

${ }^{23}$ Mowa Andrzeja Zborowskiego, kasztelana bieckiego, starosty radomskiego [zm.1598] na pogrzebie brata Samuela Zborowskiego, banity, straconego w 1583 r. przez Jana Zamojskiego, starostę krakowskiego.

${ }^{24}$ Przykład (bezimienny) mowy weselnej.

${ }^{25}$ Mowa nieznanego autora wygłoszona na weselu Waleriana Otwinowskiego (1571-1642) z Elżbietą z Wierzbiętów. Otwinowski był tłumaczem poetów rzymskich, działaczem sejmikowym i gorliwym kalwinista.

${ }^{26}$ Mowa wygłoszona na weselu Waleriana Otwinowskiego z Elżbietą z Wierzbiętów, podziękowanie Pani Otwinowskiej za upominki otrzymane po weselu od Pana Malickiego, przyjaciela Waleriana Otwinowskiego.

${ }^{27}$ Przykład (bezimienny) mowy weselnej.

${ }^{28}$ Mowa Samuela Przypkowskiego na ślubie Stanisława Kurosza z Jadwigą Grekówną w Dobryniu. Być może chodzi o córkę Stefana Greka, arianina. Fragment tej mowy cytuje: L. Chmaj, Samuel Przypkowski, s. 26-27, przypis 3. L. Chmaj podał, że odpisy tej mowy posiadała w sylwach Biblioteka Uniwersytetu Warszawskiego (sygn. Pol. XVII, 14, k. 38-40) oraz Biblioteka Ord. Krasińskich (sygn. 290, s. 270-275). Por. Pułaski, Opis, s. 430), jednak oba rękopisy zostały zniszczone podczas drugiej wojny światowej. Cytat Chmaja bardzo podobny, ale trochę się różni poszczególnymi słowami od naszego rękopisu.

${ }^{29}$ Mowa Andrzeja Moskorzowskiego wygłoszona na ślubie Jadwigi Wiktorii Wilamówny z Kaliszan z Piotrem Sieniutą (1616-1648). Piotr Sieniuta był arianinem, protektorem różnowierców. Podobna mowa z tego wesela była w rękopisie 290 Biblioteki Ordynacji Krasińskich., Por. Pułaski, Opis, jak wyżej, s. 430.

${ }^{30}$ Mowa na weselu Stanisława Firleja, późniejszego kasztelana lubelskiego z Dorotą Leśniowolską, córką starosty brańskiego, Prokopa Leśniowolskiego. Ślub odbył się w 1643 r.

${ }^{31}$ Mowa Andrzeja Moskorzowskiego na weselu Władysława Lazińskiego z Barbarą Schlichtingówną, córką Jonasza Schlichtinga. Ta sama mowa była w rękopisie nr 290 Biblioteki Ordynacji Krasińskich. Por. Pułaski, Opis, s. 430.

${ }^{32} \mathrm{Na}$ marginesie późniejsza notatka ręczna zieloną kredką: „,(por. Pułaski, Opis rękopisów, s. 430)". Chodzi o cytowaną już wielokrotnie wyżej pozycję: Franciszek Puławski, Opis 815 rękopisów Biblioteki Ordynacji Krasińkich, Warszawa 1915, s. 430. Jest tu podany opis rękopisu o sygn. 
24. Rationes cur Ecclesiae Romanae Antistites atque cives non adeo deberent esse infensi Fratribus Polonis, quos vulgo Arianos quanquam Iniuria vocant ${ }^{33}$, k. 35 r. -35 v.

25. List do Bełskiego Firleja od Ojca jego... Andreae, Filio Salutem et Paternam benedictionem ${ }^{34}$, k. 35 r. - 38 r.

26. Kallimachowe rady Królowi Janowi Albrychtowi na opressiq narodu szlacheckiego dane $^{35}$, k. 39 r. - 39 v.

27. Compendium rad Pana kanclerza koronnego Ossolińskiego, anno $1649^{36}$, k. 40 r.- $41 \mathrm{v}$.

28. Echo pod czas Rokoszu wydane, anno $1607^{37}$, k. 41 v.-42 v.

29. Drugie Echo za czwartego Władysława króla polskiego Panu podkanclerzemu koronnemu złożone, a w Opatowie na Seymiku publice porzucone in scriptis, anno $1639^{38}$, k. 42 v.

30. De eodem ex simulatio..., k. 42 v.

31. Condycye Venetom podane Pokoju Światobliwości Romanae Consistorium Rzymskiego z Inquisitiey y rady Duchowniey Hyspanskiey z Declaratiq ich $s$ którymby sposobem uspokojenie między Papieżem y Wenetami zastanowione być mogło, $z$ włoskiego przełożone ${ }^{39}$, k. 43 r. - 44 r.

290, Miscellanea historyczne z lat 1592-1713, zbiór mów przeważnie Andrzeja Moskorzowskiego, s. $426-433$.

${ }^{33}$ Ariańska rozprawka przekonująca, że arianie są chrześcijanami.

${ }^{34}$ List w języku łacińskim Mikołaja Firleja (1586-1636) do syna Andrzeja Firleja (późniejszego kasztelana lubelskiego z 1655 r.), omawiający kwestię ubiegania się przez szlachtę polską o tytuły hrabiowskie i baronowskie. Jako że w liście mowa o wuju, biskupie poznańskim [Henryku Firleju] zm. 3 XII 1634 r., można datować ten list na czas krótko przed śmiercią Henryka Firleja, a już po jego nominacji na biskupa.

${ }^{35}$ Rokoszanie Zebrzydowskiego twierdzili, że król Zygmunt III stosował się do tych rad w swojej polityce wobec szlachty. Trochę inna wersja niż opublikowana przez Aleksandra Rembowskiego. Por. Kallimachowe rady Olbrychtowi królowi podane, wedla których rokoszanie, że król się sprawowat twierdzili, w: Rokosz Zebrzydowskiego. Materiaty historyczne poprzedzone przedmowa i rozprawa pod tytułem Konfederacja i rokosz $w$ dawnem prawie państwowem polskiem, wyd. Aleksander Rembowski, Warszawa 1893, s. 365-368, w: „Biblioteka Ordynacji Krasińskich. Muzeum Konstantego Świdzińskiego”, seria 2, t. 9-12, Warszawa 1886-1892.

${ }^{36}$ Krytyka polityki i taktyki wojennej kanclerza Jerzego Ossolińskiego w czasie wojny z Tatarami i Kozakami, po ugodzie z Bohdanem Chmielnickim pod Zborowem 15 VIII 1649 r.

${ }^{37}$ Inna wersja niż opublikowana przez Aleksandra Rembowskiego, bardzo podobna w treści, ale o zebraniu rokoszan w Sandomierzu, a nie w Pokrzywnicy (jak u Rembowskiego). Por. Piaty [lament]. Na echo, w: Rokosz Zebrzydowskiego, s. 439-441.

${ }^{38}$ Utwór krytykuje pomysł Jerzego Ossolińskiego, by powołano Kawalerię Orderu Niepokalanego Poczęcia Najświętszej Marii Panny (bractwo orderowe) i przyjęcie przez niego tytułu książęcego.

${ }^{39}$ Warunki pokoju zawarte przez papieża Pawła V z Rzeczpospolitą Wenecką po zatargu Wenecji ze Stolicą Apostolską na skutek uwięzienia dwóch księży i poddania ich sądowi świeckiemu wyrokowi rady senatu weneckiego oraz wydalenia z Wenecji jezuitów, kapucynów, teatynów i minimów, którzy dochowali wierności papieżowi Pawłowi V. Po stronie papieskiej stanęła wtedy Hiszpania, mediował w tej sprawie król francuski Henryk IV. Układy prowadzono jednocześnie w 
32. De spectaculis variis Gedani Honori Regio exhibitis... ${ }^{40}$, k. 44 r.

33. Mowa Pana generała Wielgopolskiego ${ }^{41}$, k. 44 v. - 48 r.

34. Votum Pana Gdańskiego na seymie, anno $1649^{42}$, k. 48 r. - 52 r.

35. Sieroctwo Polskie albo Żałosny Lament nad zejściem $\mathrm{z}$ tego świata świętej Pamięci Niezwyciężonego Monarchy y naszego Miłościwego Pana y Króla Władysława Czwartego Króla Polskiego y Szwedzkiego, którego Pan Bóg z tego świata Królestwa doczesnego do wiecznego przenieść raczył 20 April Roku 1648 złożony z serdeczney Condolencyj Nota Pieśni Sebastianie S. Męczenniku $^{43}$, k. 52 r. - 54 r.

36. Przedmowa przy oddaniu Panny po ślubie ${ }^{44}$, k. 54 v.- 55 r.

37. Przedmowa na przenosinach przy ostatnim oddaniu Panny, k. 55 r. - 55 v. 38. Przy oddaniu Panny, k. 55 v. - 56 v.

39. Oratio reddentis Panem Panem Martium, k. 56 v. -57 r.

40. Reddentis muneris loco annulum, k. 57 r. - 58 r.

41. Oratiuncula reddentis sertum, k. 58 r.- 58 v.

42. Oddawając Pannę Panu Młodemu, k. 58 v. - 59 v.

43. Witanie Pana Młodego w polu, k. 59 v. - 60 r.

44. Oddawanie upominków, k. $60 \mathrm{r}$.

45. Witanie Pana Młodego, k. 60 v.

46. Inne witanie Pana młodego, k. 60 v.

47. Responsoria huic, k. 60 v. $-61 \mathrm{r}$.

48. Oratio reddens sponsam sponso, k. 61 r. - 61 v.

49. Oratio responsoria huic, k. $61 \mathrm{v}$.

50. Oddanie wieńca, k. 61 v. - 62 r.

51. Odpowiedź na oddanie wieńca, k. 62 r.

52. Oddanie rozmarynu, k. 62 r. - $62 \mathrm{v}$.

53. Oddanie roztruchana, k. $62 \mathrm{v}$.

54. Oddanie łańcucha, k. 62 v. - 63 r.

55. Gratiarum actio pro munere, k. 63 r. 63 v.

56. Alia gratiarum actoria, k. $63 \mathrm{v}$.

57. Alia gratiarum actio pro munere quolibet, k. $63 \mathrm{v}$.

58. Oddawanie marcypanu, k. 63 v. - 64 r.

59. Odpowiedź na oddanie marcypanu, k. 64 r. -64 v.

Rzymie i w Wenecji i 22 III 1607 r. zakończyły się one podpisaniem przez papieża Pawła V upoważnienia do zdjęcia klątwy z Wenecji po przyjęciu warunków ułożonych przez rząd wenecki.

${ }^{40}$ Anonimowy epigramat $\mathrm{w}$ języku łacińskim.

${ }^{41}$ Prawdopodobnie mowa generała małopolskiego, Jana Wielopolskiego skierowana do Jana Kazimierza. Chwali w niej męstwo króla pod Zborowem, a ugodę zborowską przedstawia jako wyraz zwycięstwa i roztropności króla.

${ }^{42}$ Mowa Stanisława Kobierzyckiego (1600-1665) kasztelana gdańskiego (VII 1643-31 VI 1656) na drugim sejmie w 1649 r., gdzie wystapił on z ostrą krytyką pospolitego ruszenia, chwali ugodę pod Zborowem i politykę króla Jana Kazimierza (uzasadnia przekazanie podarunków chanowi), chwali także dzielność wojska litewskiego.

${ }^{43}$ Elegia.

${ }^{44}$ Pozycja nr 36-82 przykłady (bezimienne) mów związanych z obrzędami weselnymi. 
60. Responsoria huic, k. 64 v. - 65 r.

61. Oratiuncula reddendo munera, k. 65 r.

62. Responsoria huic, k. 65 r.

63. Oratio in qua traditur sponsa sponso, k. 65 v. $-66 \mathrm{r}$.

64. Responsoria huic, k. 66 r. - $66 \mathrm{v}$.

65. Oratio munerum rediteria, k. 66 v. -67 r.

66. Responsoria huic, k. $67 \mathrm{r}$.

67. Oratio in thalamo haberi solita, k. $67 \mathrm{r}$.

68. Mowa przy dziękowaniu za upominek ze strony Panny, k. 67 v.

69. Druga mowa o tymże, k. 67 v - 68 r.

70. Na pierwszy przyjazd zaletny, k. $68 \mathrm{r}$.

71. Responsoria huic, k. $68 \mathrm{r}$.

72. Przy oddawaniu podarunków, k. $68 \mathrm{r}-68 \mathrm{v}$.

73. Dziękowanie za obietnice, k. 68 v.

74. Odjeżdżając po obietnicy, k. 68 v.

75. Przyjechawszy na wizytacją, k. 68 v.

76. Odjeżdżając tey Panny Rodzice pożegnać, k. 69 r.

77. Nazajutrz o przyjeździe Pana Młodego, k. 69 r.

78. Potykając Pana Młodego, k. 69 r.

79. Mowa przy oddaniu upominków od Pana Młodego, k. 69 r. -69 v.

80. Insza mowa o tymże, k. 69 v.

81. Mowa insza, k. 69 v.

82. Mowa insza, k. $70 \mathrm{r}$.

83. Votum in comitialis ${ }^{45}$, k. 70 r. - $70 \mathrm{v}$.

84. Votum consentiens, k. $70 \mathrm{v}$.

85. Votum contrarium, k. 70 v. $-71 \mathrm{r}$.

86. Oratio hortatoria, k. $71 \mathrm{r}$.

87. Responsoria huic, k. 71 r. - $71 \mathrm{v}$.

88. Oratio commendatoria, k. 71 v. -72 r.

89. Oratio petitoria, k. 72 r.

90. Alia, k. 72 r.- 72 v.

91. Responsoria huic, k.72 v.

92. Oratio accusatoria, k. 72 v.- 73 r.

93. Responsoria huic, k. 73 r.

94. Oratio consolatoria, k. 73 r.

95. Responsoria huic, k. $73 \mathrm{v}$.

96. Oratio gratiarum actoria, k. 73 v.

97. Oratio legati in comitiolis ${ }^{46}, \mathrm{k} .73 \mathrm{v}$.

98. Oratio monitoria ${ }^{47}$, k. 74 r. - 74 v.

99. Oratio genethalica, k. 74 v. -75 v.

\footnotetext{
${ }^{45}$ Pozycja 84-96, 99 - przykłady (bezimienne) mów na różne okazje.

${ }^{46}$ Mowa z okresu niewoli francuskiej królewicza Jana Kazimierza trwającej od 9 V 1638 do 25 II 1640.

${ }^{47}$ Mowa napominająca króla Władysława IV, by nie szukał żony wyznania protestanckiego, lecz katoliczki, z czasów, gdy król zamierzał poślubić Elżbietę, palatynównę reńską.
} 
100. List księcia Jerzego Zbaraskiego, kasztelana krakowskiego do księdza Marcina Szyszkowskiego, biskupa krakowskiego, w ten czas, kiedy Leo Sapieha, wojewoda wileński, człek fere octuagenarius hetmanem W. K. L. na wojnie przeciw Gustawowi, Xciu Sudermańskiemu y Szwedzkiemu Królowi zostal, Anno 1626, 26 IV $1626^{48}$, k. 75 v. - 77 r.

101. Mowa Jerzego Ossolińskiego, podkanclerzego koronnego dziękująca za pieczęć $^{49}$, k. 77 r. -79 v.

102. Oratio funebris in funere adolescentis $\mathrm{s}^{50}, \mathrm{k} .79 \mathrm{v} .-82 \mathrm{r}$.

103. Oratio funebris in funere senatoris habita, k. 82 r. -86 r.

104. In funere illustris adolescentis oratio responsoria, k. 86 r. - 88 r.

105. Relatia Xcia Janusza Radziwiłła polnego hetmana W. X. L., starosty żmudzkiego, na Seymie Warszawskim sześćniedzielnym, Anno $1652^{51}$, k. 88 r. $102 \mathrm{r}$.

106. Modus praeficiendi sive ordinandi militem inclyti et heroici Ordinis Equitum Immaculatae Virgini ${ }^{52}$ s, k. 102 v. - 107 r.

107. Diploma regium ${ }^{53}$, k. 107 r. - 107 v.

108. Statuta incliti ac Regii Ordinis Equitum Immaculatae Virginis ${ }^{54}$, k. 107 v. $113 \mathrm{v}$.

109. Urbanus Papa ${ }^{55}$, k. 113 v. - 114 v.

110. Xsięcia Radziwiłła ratie, przez które odradza Jego Królewskiej Mości, aby odmienił przedsięwzięcie swoje $\mathrm{w}$ ordynowaniu cavaleriey, albo przynajmniey, żeby się zatrzymał aż do seymu ${ }^{56}$, k. 114 v. - 118 r.

${ }^{48}$ List Jerzego Zbaraskiego, kasztelana krakowskiego do Marcina Szyszkowskiego, biskupa krakowskiego z okresu, gdy Lew Sapieha prowadził wojnę ze Szwedami jako nowo wybrany hetman wielki litewski. Lew Sapieha (1557-1633) został mianowany na hetmana 25 VII 1625 r., mając lat sześćdziesiąt dziewięć, a nie jak podano w liście prawie osiemdziesiąt. Data podana w rękopisie dotyczy czasu pisania listu, a nie nominacji. Zob. hasło Sapieha Lew, w: PSB, t. 35, s. 96-97.

${ }^{49}$ Nominację na podkanclerzego koronnego Jerzy Ossoliński otrzymał 20 III 1638 r., funkcję tę sprawował do 28 II $1643 \mathrm{r}$.

${ }^{50}$ Pozycje nr 101-103 - przykłady (bezimienne) mów pogrzebowych.

${ }^{51}$ Janusz Radziwiłł 26 III 1652 r. złożył relację z przebiegu działań armii koronnej i litewskiej w czasie kampanii moskiewskiej.

${ }^{52}$ Zasady przygotowania, powołania i utworzenia Kawalerii Orderu Niepokalanego Poczęcia Najświętszej Marii Panny spisane prawdopodobnie przez Jerzego Ossolińskiego, który był pomysłodawcą utworzenia królewskiej kawalerii.

${ }^{53}$ Odpis dokumentu króla Władysława IV, w którym powołuje kawalerię.

${ }^{54}$ Statut kawalerii.

${ }^{55}$ List papieża Urbana VIII (1623-1644) z dnia 5 lipca 1637, w którym mówi o inicjatywie Jerzego Ossolińskiego i Władysława IV dotyczącej utworzenia kawalerii.

${ }^{56}$ Krzysztof Radziwiłł był przeciwny zamiarowi króla Władysława IV i Jerzego Ossolińskiego, by utworzyć kawalerię Orderu Niepokalanego Poczęcia Najświętszej Marii Panny. Przemówienie w tej sprawie wygłosił w obecności króla (w lipcu?) 1637, w tym samym roku ogłosił ją drukiem „Rationes przeciwko Kawalerii”. 
111. Co za pożytek Korona Polska odniosła z pruskiey woyny z Gustawem ${ }^{57}$, k. 118 v. -122 r.

112. Evolutio paradoxi albo consideratia listu jakiegoś polityka strony pożytków woyny pruskiey y ceł morskich ${ }^{58}, \mathrm{k} .122$ r. - $126 \mathrm{v}$.

113. Jan Kazimierz ${ }^{59}$, k. 126 v. -127 r.

114. Jan Kazimierz ${ }^{60}$, k. 127 r. -127 v.

115. Jan Kazimierz ${ }^{61}$, k. 127 v. -128 v.

116. Exelentissimi Domini D. Jacobi Cat. Praep[osi]t[i] Ordinum Foeder. Belgii Legati apud Anglos oratio in occasione pugnae navalis recenter commissae coram Illustrissibus Proceribus Parlamenti Anglicani habita, k. 128 v. - 130 $r$.

117. Jan Kazimierz ${ }^{62}$, k. 130 r. - 130 v.

118. Statua memorialis super obitu defunctae Piissimae et Desiderantissimae faemineae [Mariae Henningae] erecta, Elbingae 25 septembris 1643, cond. et scrib. Mychael Mylius Gymnasii rector ${ }^{63}$, k. 131 v. -132 v.

119. Audi Viator ${ }^{64}$, k. 132 v. - 133 v.

120. Epigramma ${ }^{65}$, k. 133 v. -134 r.

121. Epitaphium ${ }^{66}$, k. 134 r.

122. Epitaphium ${ }^{67}$, k. 134 r.

123. Epitaphium ${ }^{68}$, k. 134 v.

${ }^{57}$ Mowa jakiegoś polityka katolickiego rozważająca skutki wojny pruskiej z Gustawem II Adolfem po pokoju w Altmarku (Starej Wsi) w 1629 r., kiedy to Rzeczpospolita straciła miasta portowe (Elblagg) i nadmorskie w Prusach Zachodnich, a Gdańsk został zmuszony płacić Szwedom $3,5 \%$ cło. Autor dużą winę przypisuje tutaj dysydentom.

${ }^{58}$ Replika na powyższą mowę autora protestanckiego, który broni wierności dysydentów i zaprzecza jakoby poddali się Szwedom.

${ }^{59}$ Uniwersał Jana Kazimierza, wydany w Warszawie 11 V 1652, w którym król mówi o rozgromieniu wojsk koronnych po zerwanym w styczniu 1652 r. sejmie i nakazuje mobilizację wojska kwarcianego i pospolitego ruszenia.

${ }^{60}$ Uniwersał Jana Kazimierza, wydany w czerwcu 1652 r. w Warszawie, w którym mówi o klęsce wojsk koronnych pod Batohem i braku wiadomości o hetmanie polnym koronnym. Dnia 2 VI hetman polny koronny Mikołaj Kalinowski poniósł druzgoczącą klęskę z wojskami Chmielnickiego pod Batohem i tam też poległ.

${ }^{61}$ List Jana Kazimierza z czerwca 1652 (Warszawa) do NN mówiący o zdradzie Hieronima Radziejowskiego i jego ucieczce do Sztokholmu, na dwór królowej szwedzkiej Krystyny.

${ }^{62}$ Uniwersał Jana Kazimierza po oblężeniu Kamieńca Podolskiego przez wojska Chmielnickiego, musiał być więc pisany po 17 VI 1652, brak końca dokumentu.

${ }^{63}$ Epitafium w języku łacińskim poświęcone Marii Henning autorstwa Michaela Myliusa (1603-1652) rektora gimnazjum elbląskiego, syna Jana Myliusa (1557-1630).

${ }^{64}$ Anonimowe epitafium w języku łacińskim.

${ }^{65}$ Epigramat w języku łacińskim autorstwa Godofredusa Richterusa, był to uczeń gimnazjum elbląskiego.

${ }^{66}$ Epitafium w języku łacińskim Godofredusa Richterusa.

${ }^{67}$ Anonimowe epitafium w języku łacińskim.

${ }^{68}$ Anonimowe epitafium w języku łacińskim. 
124. Viator ${ }^{69}$, k. $134 \mathrm{v}$.

125. Sacra sunt haec memoriae ${ }^{70}$, k. 134 v. $-135 \mathrm{r}$.

126. Piis manibus ${ }^{71}$, k. 135 r. - 135 v.

127. Epitaphium Cavaleriae ${ }^{72}$, k. 135 v. - 136 r.

128. Responsio novi quondam in Polonia Imperii Principis ad scriptum recens filiae suae epitaphium ${ }^{73}$, k. 136 r. - 136 v.

129. De inscriptionis epitaphicis ${ }^{74}$, k. 136 v. - 137 v.

130. Epitaphium Summo Pontifici Bernardo Cordubensi P. Maximo ${ }^{75}$, k. 137 v.

131. Jesu Christi Spei et Fidelium Vate Paulo IV Caraffe P. Maximo, k. 137 v.

132. Hadriano VI Pont. Maximo, k. 137v. - 138 r.

133. Marcellus II Pontifex Maximus, k. 138 r.

134. Adrianus VI, k. $138 \mathrm{r}$.

135. Epitaphium Sigismundi Tertii Poloniae Regis ${ }^{76}$, k. 138 r.

136. Epitaphium Pueri Nobilis, k. 138 r. - 138 v.

137. Stephanus M. Rex Poloniae, k. 138 v.

138. Epitaphium Nobilis D. O. M., k. 139 r.

139. Nobilis in Duello vel alia occasione ${ }^{77}$, k. 139 r. -139 v.

140. Pemptas Epigrammatica opposita ${ }^{78}, \mathrm{k} .139 \mathrm{v}$.

141. Pemptas epigrammatica ad eximium Christi ministrum Martinum Gratianum $^{79}$, k. 139 v. - 140 r.

142. Jesuita Jacobus Wujek Postillae Catholicae sub nomine Serenissimorum Poloniae Regis et Reginae idiomatae Polonico editae, parte secunda ${ }^{80}$, k. 140 r. $-142 \mathrm{r}$.

${ }^{69}$ Anonimowe epitafium w języku łacińskim.

${ }^{70}$ Anonimowe epitafium w języku łacińskim.

${ }^{71}$ Stylizowany na epitafium łaciński pamflet na nieudany i niezrealizowany pomysł Jerzego Ossolińskiego powołania Kawalerii Orderu Niepokalanego Poczęcia Najświętszej Marii Panny. Jest to utwór Samuela Przypkowskiego, który napisał kilka pamfletów na ten temat. Cieszyły się one dużą popularnością i zachowane są do dziś w wielu kopiach i przeróbkach. Drukowany m.in. Chmaj, Samuel Przypkowski, s. 187.

${ }^{72}$ Jest to kolejna dobrze znana wersja pamfletu na kawalerię napisanego prawdopodobnie przez Samuela Przypkowskiego. Zob. hasło: Przypkowski Samuel, w: PSB, t. 29, s. 228.

${ }^{73}$ Kolejny utwór na ten sam temat. Ironicznie nazwano tutaj kawalerię córką byłego księcia. Trudno stwierdzić, czy jest to koleja wersja pamfletu Przypkowskiego czy jest to przeróbka innego autora. L. Chmaj stwierdza, że tylko Piis manibus ma autorstwo pewne. Zob. Chmaj, Samuel Przypkowski, s. 186-188.

${ }^{74}$ Wykład z poetyki na temat sposobu pisania epitafiów. Być może jest to wykład nauczyciela gimnazjalnego lub fragment przepisany z jakiejś publikowanej poetyki.

${ }^{75}$ Według informacji podanej przez autora sylwy kolejne pozycje (nr 130-134) stanowią epitafia łacińskie cytowane z dzieła Francisca Sicerciusa, Orbis Christianae deliciae.

${ }^{76}$ Pozycje nr 134-137 stanowią epitafia w języku łacińskim poświęcone polskim królom.

${ }^{77}$ Epitafium w języku łacińskim anonimowe.

${ }^{78}$ Pamflet łaciński przeciwko jezuitom.

${ }^{79}$ Pamflet na nieznanego bliżej ministra ariańskiego (lub kalwińskiego) Marcina Gracjana, który prawdopodobnie wstapił do zakonu jezuitów.

${ }^{80}$ Pamflet łaciński przeciwko jezuitom. 
143. Epigramma ad observandum in Christo fratrem Martinum Gratianum ${ }^{81}$, k. $140 \mathrm{v}$.

144. Cippus ad tumulum unionis erectus ${ }^{82}$, k. 140 v. - 142 r.

145. De Polonia ${ }^{83}$, k. 142 r.

146. Aenigma de Phaenice Pontificis, k. 142 r.

147. Gerardus Vossius Amsterd. Ungaro Domino Stephano Beniamino Siylagy, k. $142 \mathrm{v}$.

148. Ad sacram et Serenissimam Reginam Poloniam, Poloniae et Sueciae Dominam, Dominam Clementissimam ${ }^{84}, \mathrm{k} .142 \mathrm{v}$.

149. Rycerstwo Jezuickie w Poznaniu $1596^{85}$, k. 142 r.

150. Grozi nam Pan Bóg ${ }^{86}$, k. 143 r. - 143 v.

151. Oratiuncula genethliaca polonica ${ }^{87}$, k. 143 v. -144 v.

152. Exemplum oratiunculae reddentis muneris loco annulum, k. $144 \mathrm{v} .-145 \mathrm{r}$.

153. Oratiuncula reddentis sertum, k. 145 r. - 145 v.

154. Oratiuncula reddentis Panem Martium, k. 145 v. - 146 r.

155. Exemplum orationis polonicae senatoris parentantis ${ }^{88}$, k. 146 r. - 149 r.

156. Exemplum orationis funebris legati senatoris ${ }^{89}, \mathrm{k} .149 \mathrm{r}$.

157. List Hieronima Radziejowskiego, podkanclerzego koronnego do Bohdana Chmielnickiego, hetmana wojska zaporowskiego z dnia 30 V 1652 w Sztokholmie ${ }^{90}, \mathrm{k} .149 \mathrm{r}-150 \mathrm{v}$.

158. List Hieronima Radziejowskiego, podkanclerzego koronnego do pisarza wojska zaporowskiego z dnia 30 V 1652 w Sztokholmie ${ }^{91}$, k. 150 v.

\footnotetext{
${ }^{81}$ Pamflet na Marcina Gracjana, zob. przypis 71.

${ }^{82}$ Utwór polityczno - religijny z datą kwiecień 1621.

${ }^{83}$ Krytyka Polski z czasów ostatnich chwil panowania Zygmunta III Wazy.

${ }^{84}$ Anonimowy epigramat łaciński.

${ }^{85}$ Wiersz przekreślony, a dalsza cześć wyrwana - brak trzech kart z dawną paginacją s. 278-283. Jest to paszkwil na jezuitów. Brak dalszej części utworu.

${ }^{86}$ Utwór w języku polskim, bez tytułu, datowany jest na 5 X 1601.

${ }^{87}$ Pozycje $\mathrm{nr}$ 150-153 anonimowe i bezimienne mowy weselne.

${ }^{88}$ Anonimowy, bezimienny przykład pouczającej mowy senatorskiej.

${ }^{89}$ Anonimowy, i bezimienny przykład mowy na pogrzebie posła senatora.

${ }^{90}$ List Hieronima Radziejowskiego do Bohdana Chmielnickiego, hetmana wojska zaporow-
} skiego, napisany w Sztokholmie 30 V 1652. Radziejowski, będąc na dworze królowej szwedzkiej Krystyny 31 V 1652 wysłał przez szlachcica Władysława Jasińskiego listy do Bohdana Chmielnickiego, Iwana Wyhowskiego, Janusza Radziwiłła, Władysława Dominika Zasławskiego i Jerzego II Rakoczego. Jasiński wyruszył na Ukrainę dopiero w końcu lipca 1652, kilka dni po otwarciu 23 VII sejmu w Warszawie. 4 VIII został przypadkowo pojmany w Berdyczowie i na polecenie hetmana Stanisława „Rewery” Potockiego odesłany w kajdanach na sejm, gdzie w ostatnich dniach obrad owe listy przedstawiono jako ostateczny dowód zdrady Radziejowskiego. Powyższe listy są właśnie odpisami tych przedstawionych na sejmie. W liście do Chmielnickiego Radziejowski oznajmia, że prosił królową Krystynę o pomoc dla niego.

${ }^{91}$ List Hieronima Radziejowskiego do Iwana Wyhowskiego, pisarza wojska zaporowskiego $\mathrm{z}$ dnia $30 \mathrm{~V} 1652 \mathrm{r}$. Zob. poprzedni przypis. 
159. Manifestatio innocentiae illustrissimi excelentissimi D. Hieronymi in Radziejowice Radziejowski Procancellarii Regni ${ }^{92}$, k. 151 r. - 153 v.

160. Vladislaus Dominicus Dux in Ostrog et Zaslaw ${ }^{93}$, k. 153 v. - 156 r.

161. Litera Regis Vladislai IV ad Portam Ottomanicam ${ }^{94}$, k. 156 r. - 157 v.

162. Gustavi Adolphi Tumulus ${ }^{95}$ r. k. 157 v.

163. Innocentiae Theatrum erectum suspiriis Anglicanis ${ }^{96}$, Estoni Anglicorum 25 Ianuar. 1630, k. 158 r.

164. Illustrissimi Viri Joannis Skytae, serenissimimi Gustavi II Suec., Gothorum Vandalorum etc. Regis Legati orationes tres habitae ad serenissimum Magnae Britaniae Regem ${ }^{97}$, k. 158 v. - 174 v.

165. Postillion ${ }^{98}$, k. 175 r. - 178 r.

166. Puncta supliki do Najjaśniejszego Majestatu Pana Naszego Miłościwego y do Oświeconego Senatu i Wszystkiey Rzeczypospolitej Bohdana Chmielnickiego hetmana wojska zaporowskiego ${ }^{99}, \mathrm{k} .178$ r. - $178 \mathrm{v}$.

167. Respons na to od P. hetmana polnego ${ }^{100}$, k. 178 v. 179 r.

168. Deo immort. et memoriae posthume Annae de Lesno Potociae ${ }^{101}$, k. 179 r. $179 \mathrm{v}$.

169. In Poloniam ${ }^{102}$, k. 179 v. - 180 r.

${ }^{92}$ Manifestacja niewinności Hieronima Radziejowskiego. Kilka dni po wydaniu konstytucji z dnia 17 VIII 1652 „Paene perduellionis na Hieronimie Radziejowskim przeszłym podkanclerzym koronnym” agent szwedzki J. Kock przywiózł pakiet listów z dnia 20 VII wraz z Manifestatio innocentie - drukowanej obrony Radziejowskiego oraz list królowej Krystyny wstawiający się za nim.

${ }^{93}$ Glejt żelazny Władysława Dominika Zasławskiego wydany Hieronimowi Radziejowskiemu po 20 I 1652 (kiedy to skazano Radziejowskiego na śmierć, infamię i konfiskatę dóbr) a przed 30 I 1652 r. (kiedy powołano go na sąd sejmowy). Zasławski wydał ten dokument jako dostojnik dla obywatela niedopuszczonego przed sąd - mógł taki glejt wydać na podstawie dawnego, bo pochodzącego jeszcze z 1368 roku prawa Kazimierza Wielkiego.

${ }^{94}$ List Władysława IV do sułtana Amuratha, nie datowany, po sejmie warszawskim.

${ }^{95}$ Epitafium dla króla szwedzkiego Gustawa Adolfa napisane przez nieznanego bliżej autora o inicjałach S. J. w Antwerpii 1649. W istocie jest to pamflet przeciwko królowi szwedzkiemu

${ }^{96}$ Napisany w Estonii 25 I 1630 utwór w języku łacińskim o charakterze polityczno-religijnym nieznanego autora.

${ }^{97}$ Trzy mowy w języku łacińskim Jana Skytte, posła króla szwedzkiego Gustawa II Adolfa do króla angielskiego. Pierwsza mowa jest z 22 VII 1610, druga z 10 XII 1617, trzecia z 1618 roku przedstawia historię konfliktu polsko-szwedzkiego. O postaci Jana Skytte wiadomo z całą pewnością, że w 1633 był szwedzkim gubernatorem Inflant

${ }^{98}$ Wiersz niemiecki nieznanego autora.

${ }^{99}$ Warunki pokoju przedstawione przez Bohdana Chmielnickiego królowi Janowi Kazimierzowi po bitwie pod Batohem 2 VI i oblężeniu Kamieńca Podolskiego ok. 17 VI 1652. Obarcza tutaj winą za zaszłe wypadki poległego hetmana polnego koronnego Mikołaja Kalinowskiego.

${ }^{100}$ Odpowiedź na powyższą suplikę Chmielnickiego od Stanisława „Rewery” Potockiego, hetmana polnego koronnego, który nominację hetmańską otrzymał po śmierci M. Kalinowskiego, pod koniec czerwca 1652.

${ }^{101}$ Epitafium poświęcone Annie z Leszczyńskich Potockiej, żonie Jana Teodoryka Potockiego, podkomorzego halickiego, zmarłej $4 \mathrm{~V} 1653$.

${ }^{102}$ Utwór nieznanego autora, prawdopodobnie łacińska wersja wiersza pt. Adieu à la Pologne 
170. Polonorum epitasis ${ }^{103}$, k. 180 r. - 180 v.

171. Johannes Cochanovius Gallo crocitanti ${ }^{104}$, k. 180 v. 182 r.

172. Mowa na pogrzebie Syna Księcia Pana hetmana polnego W. K. L. ${ }^{105}$, k. 182 r. - $184 \mathrm{r}$.

173. Sireni Balticae ${ }^{106}$ Constantiae Sirenbergiae ${ }^{107}$, k. 184 r. - 188 r.

174. Epitaphium Regis Sueciae Gustavi Adolphi, k. 188 r.

175. Magno Magnae Britanniae Regi Carolo, k. 188 r. - 188 v.

176. De iudicibus tactionis indepentium, k. 189 r.

177. In Wilhelmum Laud archiepiscopum Cantuariensem, k. 189 r.

178. Ad Ferdinandum II Caesarem, k. 189 r. - 189 v.

179. In pacificationem Osnaburgensem, k. $189 \mathrm{v}$.

180. In colloquium Thorunnesem $1645^{108}, \mathrm{k} .189 \mathrm{v}$.

181. In mortem card. infantis, k. 189 v. - 190 r.

182. In Nigrinum bis Lutherum, bis Calvinistam et si Deus Placet semel Futurum Catholicum ${ }^{109}$, k. 190 r.

183. Epitaphium Fridlandiae Ducis Anno $1634^{110}$, k. 190 r. - 190 v.

184. Patria inter Scyllam et Charibdim, k. 191 r. - 192 v.

185. Mowa na Pogrzebie, k. 192 v. - 194 r.

186. Mowa Pana Wiesołowskiego Marszałka nadwornego W.K.L. na weselu Księcia Aleksandra Radziwiłła ${ }^{111}$, k. 194 r. - 195 v.

187. Mowa na pogrzebie Pana starosty trąbskiego, k. 195 v. - 197 r.

Philippe Desportesa, francuskiego poety krytykującego Polskę, na który dał później replikę Jan Kochanowski.

${ }^{103}$ Pochwała Polski, replika na poprzedni utwór.

${ }^{104}$ Replika patriotyczna Jana Kochanowskiego z roku 1576 na wiersz francuskiego poety Philippe Desportesa pt. Adieu à la Pologne, w którym Francuz szkaluje Polskę i Polaków i wyśmiewa polskie miasta i obyczaje, by usprawiedliwić ucieczkę króla Henryka Walezego. Wiersz krążył w wielu odpisach wśród okolicznościowej ulotnej literatury politycznej, utwór Jana Kochanowskiego ukazał się drukiem w Lirycorum libellus z $1612 \mathrm{r}$.

${ }^{105}$ Mowa na pogrzebie Jerzego Radziwiłła (1616-1617), syna Krzysztofa Radziwiłła (15851640) i Anny Kiszczanki.

${ }^{106}$ Pozycja nr 173-183 utwory polityczne w języku łacińskim nieznanych autorów

${ }^{107}$ Panegiryk w języku łacińskim na cześć Konstancji Sirenberg.

${ }^{108}$ W Toruniu w dniach 28 VIII-21 XI 1645 odbyło się spotkanie przedstawicieli wyznania katolickiego, luterańskiego i kalwińskiego zwane colloquium charitativum, na którym radzono nad sposobem zjednoczenia wyznań chrześcijańskich.

${ }^{109}$ W tekście błędnie Rufinus Nigrinus, powinno być Bartolomeus Nigrinus, z urodzenia socynianin, potem luteranin, następnie ksiądz kalwiński, a na koniec katolik. Był on pomysłodawcą połączenia wszystkich religii chrześcijańskich i to za jego namową Władysław IV zwołał kolokwium toruńskie.

${ }^{110}$ Epitafium poświecone Albrechtowi Wallenstein, księciu Friedlandu, zamordowanemu na rozkaz cesarza Ferdynanda II dnia 25 II 1634 w Pilznie. W rękopisie kopista zaznaczył, że epitafium było napisane 12 I 1634 na krótko przed śmiercią księcia, autor broni jego wierności wobec cesarza w momencie, gdy groziło mu niebezpieczeństwo utraty życia na skutek oskarżenia o zdradę stanu.

${ }^{111}$ Mowa Krzysztofa Wiesiołowskiego na weselu Aleksandra Radziwiłła z Teklą Wołłówiczówną w Grodnie 10 V 1626 r. 
188. Mowa po szlubie oddając Pannę ${ }^{112}$, k. 197 r. - 199 v.

189. Dziękowanie za uczciwe wychowanie, k. 199 v. - 200 r.

190. Mowa Księcia Bogusława Radziwiłła przed Królem w senacie przy sprawie anno 163125 febr. ${ }^{113}$, k. 200 r. - 201 v.

191. Mowa Księcia Pana hetmana polnego W. K. L. na Convocatiey Warszawskiey w Izbie Poselskiey, gdy unanimi consensu directorem y marszałkiem koła poselskiego był obrany anno 1632 die 22 iunii $^{114}$, k. 200 v. - 201 r.

192. Tamże tegoż dnia, gdy się z tego marszałkowstwa wymówić żadną miarą nie móg1 ${ }^{115}$, k. 201 r. $-201 \mathrm{v}$.

193. Tegoż dnia gdy króla Władysława ${ }^{116}$ privatim witał, k. 201 v.

194. Mowa tegoż Księcia dnia 23 iunii do Królewiczów Pięciu, gdy ich jako marszałek poselski imieniem wszystkiego nota cum compassione witał ${ }^{117}$, k. 201 v. $-202 \mathrm{v}$.

195. Mowa tegoż Księcia do królewny imieniem koła poselskiego die 26 iunii $^{118}$, k. $202 \mathrm{v}$.

196. Mowa tegoż Księcia gdy publico nomine Królewicowi Władysławowi dziękował za ofiarowaną po sejmikach przed convocatią odprawowanych pewną liczbę ludzi, które J. K. M. z zbioru po K. J. M. zmarłym Ojcu swym na potrzebę R.P. pod ten czas interregni zaciagnąć obiecował, k. 202 v. - 204 r.

197. Mowa tegoż Księcia po wysłuchaniu vot senatorskich w izbie senatorskiej miana 28 iunii, k. 204 r. - 205 r.

198. Respons Pana Piotra Kochlewskiego dziękując imieniem Paniey Marszałkowej Bracławskiey za podarunek od Króla J. M. ofiarowany przez P. Mścisławskiego na weselu P. Władysława Dorohostayskiego 12 febr. [1634] ${ }^{119}$, k. 205 v.

${ }^{112}$ Pozycja nr 187-188 - bezimienne przykłady mów weselnych.

${ }^{113}$ Mowa Bogusława Radziwiłła wygłoszona po śmierci stryja Krzysztofa Radziwiłła. W rękopisie błędna data, powinno być zapewne 25 II 1641 r., gdyż Krzysztof Radziwiłł zmarł 19 XI 1640, natomiast w 1631 roku Bogusław miał zaledwie 11 lat.

${ }^{114}$ Mowa Krzysztofa Radziwiłła wygłoszona 22 VI 1632 r. na sejmie konwokacyjnym, który odbył się w Warszawie 22 VI - 17 VII 1632 r. Krzysztof Radziwiłł został wówczas wybrany na marszałka sejmu. Druk. w: Księcia Krzysztofa Radziwitla hetmana polnego Wielkiego Księstwa Litewskiego sprawy wojenne i polityczne 1621-1632, Paryż 1859, s. 611.

${ }^{115}$ Mowa Krzysztofa Radziwiłła z dnia 22 VI 1632 r. Druk w: Księcia Krzysztofa Radziwitła, s. 611-612.

${ }^{116}$ Mowa Krzysztofa Radziwiłła do królewicza Władysława wygłoszona 22 VI 1632 r. Władysław podczas bezkrólewia po śmierci ojca tytułował się królem Szwecji.

${ }^{117}$ Mowa Krzysztofa Radziwiłła witającego Władysława, Jana Kazimierza, Jana Alberta, Karola Ferdynanda i Aleksandra Karola podczas sejmu konwokacyjnego, wygłoszona 23 VI 1632 r. Druk w: Księcia Krzysztofa Radziwiłła, s. 613.

${ }^{118}$ Mowa Krzysztofa Radziwiłła do Anny Katarzyny Konstancji Wazówny wygłoszona 26 VI 1632 r. Druk w: Księcia Krzysztofa Radziwiłła, s. 612.

${ }^{119}$ Władysław Dorohostajski poślubił Elżbietę Katarzynę, córkę Jerzego Samsona Podbereskiego, marszałka bracławskiego dnia 12 II $1634 \mathrm{r}$. 
199. Tegoż dziękując od Paniey Marszałkowey za podarek imieniem Pana Dorohostayskiego ofiarowany $1634^{120}$, k. 206 r. - 206 v.

200. Tegoż dziękując od Paniey Dorohostayskiey za upominek od Pana młodego ofiarowany ${ }^{121}$, k. 207 r.

201. Tegoż dziękując za upominek P. Wojewodzie Bełskiemu przez P. Naborowskiego ofiarowany ${ }^{122}$, k. 207 r. - 208 r.

202. Copia listu Księcia Pana hetmana polnego litewskiego do księcia Pana kanclerza W.K.L. ${ }^{123}$, k. 208 r. - 208 v.

203. Copia listu K. J. M. Władysława IV na Convocatią Wileńską ${ }^{124}$, k. 208 v. $209 \mathrm{r}$.

204. Copia listu Księcia Janusza Radziwiłła z cudzych krajów pisane do Króla Władysława IV dziękując za zlecenie trojakiego poselstwa do potentatów chrześcijańskich $^{125}$, k. 209 r. - 210 r.

205. List Królewicza Władysława do Księcia Krzysztofa Radziwiłła W. K. L. podczas interregnum pisany $1632^{126}$, k. 210 r. -211 r.

206. List Księcia Albrychta Stanisława Radziwiłła Kanclerza W. K. L. do Księcia Krzysztopha Radziwiłła hetmana W. K.L. pisany $1632^{127}$, k. 211 r. - 212 r.

207. Respons Księcia Pana Krzysztofa Radziwiłła hetmana W.K. L. na list Królewica Władysława szwedzkiego roku $1632^{128}$, k. 212 r. - 212 v.

208. Copia responsu Księcia pana hetmana polnego do Księcia Albrychta Stanisława Radziwiłła Canclerza W.K.L. roku $1632^{129}$, k. 212 v. - 213 v.

209. List Księcia Krzysztopha Radziwiłła hetmana polnego W.K.L. do króla Zygmunta III z Nitawy 3 Martii $1638^{130}$, k. 213 - v.216 v.

${ }^{120}$ Piotr Kochlewski dziękuje w imieniu Pani Podbereskiej, żony marszałka bracławskiego Jerzego Samsona Podbereskiego za upominek od Władysława Dorohostajskiego.

${ }^{121}$ Piotr Kochlewski dziękuje w imieniu panny młodej Elżbiety Katarzyny Dorohostajskiej za upominek od pana młodego Władysława Dorohostajskiego.

${ }^{122}$ Piotr Kochlewski dziękuje za upominek dla młodej pary Dorohostajskich przekazany przez Daniela Naborowskiego od Rafała Leszczyńskiego, wojewody bełskiego (25 VI 1619-29 III 1636).

${ }^{123}$ List Krzysztofa Radziwiłła do Albrychta Stanisława Radziwiłła.

${ }^{124}$ Uniwersał króla Władysława IV na konwokację Wileńską pisany w obozie pod Smoleńskiem w $1634 \mathrm{r}$.

${ }^{125}$ W końcu 1632 roku nowo obrany król Władysław IV zlecił Januszowi Radziwiłłowi (16121655), by powiadomił Holenderskie Stany Generalne, infantkę Izabelę jako namiestnika króla hiszpańskiego w Niderlandach oraz króla angielskiego Karola I Stuarta o wybraniu go królem Polski. List napisany przed tymi poselstwami, czyli albo w ostatnich dniach 1632 do 4 I 1633, kiedy to Janusz Radziwiłł rozpoczął już poselstwo.

${ }^{126}$ List królewicza Władysława do Krzysztofa Radziwiłła z dnia 15 V 1632 r., w którym prosi o poparcie w czasie elekcji.

${ }^{127}$ List z 18 V 1632 zachęcający do poparcia kandydatury Władysława.

${ }^{128}$ List napisany po 15 V 1632. Radziwiłł wspomina tu o swoim słudze Stanisławie Kuroszu, którego posłał do królewicza. Nie potwierdza na kogo będzie głosował.

${ }^{129}$ Odpowiedź Krzysztofa Radziwiłła na list Albrychta Stanisława, napisana po 18 V 1632. W liście mówi o eksorbitacjach, za którymi optuje i o niewłaściwym politycznie używaniu przez Władysława tytułu króla szwedzkiego.

${ }^{130}$ Pomyłka kopisty w dacie rocznej. Chodzi zapewne o rok 1628. 
210. Palma jagiellowska R. $1636^{131}$, k. 216 v. -226 r.

211. De familia Radziwiliana $\mathrm{z}$ manuscriptów N. insigniora quaedam excerpta ex ore Księcia Jego Mości ${ }^{132}$, k. 226 v. - 228 v.

212. Rationes oppositae scriptowi Macieja Dragockiego iż domowi Radziwiłłowskiemu w Koronie y w Litwie iure et merito Tituł Xsiążęcy należy ${ }^{133}$, k. 228 v. $-230 \mathrm{v}$.

213. Arbor exquisitissima Familiei Radziwilowskiej ${ }^{134}$, k. 231 v. - 233 r.

214. Copia listów różnych od Księcia Nieboszczyka Pana wojewody pisanych: Copia do króla podczas wesela jego pisanych ${ }^{135}$, k. 233 v.

215. Copie listów przyczynnych za Panem Gruszewskim o sędziostwo żmudzkie do Pana podkomorzego koronnego ${ }^{136}$, k. 233 v. - 234 r.

216. Do księdza referendarza litewskiego ${ }^{137}$, k. 234 r.

217. Kopia listu do Króla podczas seymu pisanego ${ }^{138}$, k. 234 r. - 234 v.

218. Kopia listu do księdza arcybiskupa gnieźnieńskiego pod tenże czas ${ }^{139}$, k. 234 $\mathrm{V}$.

219. W tejże materiey do Pana Krakowskiego ${ }^{140}$, k. 234 v. -235 r.

220. Copia listu do Pana marszałka nadwornego koronnego ${ }^{141}$, k. 235 r.

221. List bez intytulacji adresata ${ }^{142} \mathrm{w}$ sprawie „Conferentie z Panem wojewoda wileńskim, smoleńskim y panem podkomorzym oszmiańskim strony diffe-

${ }^{131}$ Anonimowy panegiryk na cześć Władysława IV.

${ }^{132}$ Historia domu Radziwiłłów od Mikołaja Radziwiłła do pielgrzymki Krzysztofa Radziwiłła „Pioruna” do Ziemi Świętej, opisana przez Jana Radwana w Radziwiliadzie.

${ }^{133}$ Prawdopodobnie replika na wydarzenia z sejmu w 1638, kiedy to wystapiono o zniesienie tytułów książęcych i hrabiowskich w Polsce.

${ }^{134}$ Drzewo genealogiczne Radziwiłłów.

${ }^{135}$ Krzysztof Radziwiłł do króla Władysława IV po weselu króla z Cecylią Renatą we wrześniu 1637 r. w Warszawie.

${ }^{136}$ List Krzysztofa Radziwiłła do Adama Kazanowskiego, podkomorzego koronnego (15 VIII 1634-X 1642) w sprawie starań o sędziostwo żmudzkie dla Jerzego Gruszewskiego, który otrzymał ten urząd w 1636.

${ }^{137}$ List Krzysztofa Radziwiłła do księdza Marcjana Tryzny, referendarza litewskiego (18 III 1631-30 VIII 1641), w sprawie jak wyżej.

${ }^{138}$ Krzysztof Radziwiłł chorobą tłumaczy swą nieobecność na sejmie, list pisany był zatem w 1638 , bo wtedy z powodu złego stanu zdrowia nie był obecny na obradach, które trwały od 10 III do $1 \mathrm{~V} 1638$.

139 List Krzysztofa Radziwiłła do Jana Wężyka, arcybiskupa gnieźnieńskiego (1627-27 V 1638)

${ }^{140}$ List Krzysztofa Radziwiłła do Stanisława Lubomirskiego, wojewody krakowskiego (19 I 1638-16 VI 1649), późniejszego teścia Albrychta Stanisława Radziwiłła.

${ }^{141}$ List Krzysztofa Radziwiłła do Stanisława Przyjemskiego, marszałka nadwornego (XII 1630$-28 \times 1642)$.

${ }^{142}$ List do Aleksandra Gosiewskiego prawdopodobnie autorstwa Stefana Paca, który wyznaczył na swoich pośredników i pełnomocników Adama Sakowicza, podkomorzego oszmiańskiego i Aleksandra Sawgowicza, skarbnika wiłkomierskiego, celem wymiany korespondencji z Aleksandrem Gosiewskim w swoim imieniu. 
rency pewnych po weselu Paniey Tomaszowey Sapieżiney między Księciem a Panem Podkanclerzym Litewskim zachodzących"143, k. 235 v. - 237 v.

222. List do wojewody smoleńskiego [w sprawie jak wyżej] ${ }^{144}, \mathrm{k} .235 \mathrm{v}$.

223. List do podkomorzego oszmiańskiego [w sprawie jak wyżej] ${ }^{145}$, k. 236 r. k. $236 \mathrm{v}$.

224. List trybunału przez Pana skarbnika wiłkomierskiego pisany [w sprawie jak wyżej ${ }^{146}$, k. 236 v.

225. List do podkomorzego oszmiańskiego [w sprawie jak wyżej] ${ }^{147}$, k. 236 v. k. $237 \mathrm{r}$.

226. List do wojewody smoleńskiego [w sprawie jak wyżej ${ }^{148}$, k. 237 r.

227. List do wojewody smoleńskiego [w sprawie jak wyżej ${ }^{149}, \mathrm{k} .237 \mathrm{r}$.

228. List do wojewody smoleńskiego [fragment ucięty, w sprawie jak wyżej], k. 237 r. - k. 237 v.

229. Fragment łacińskiej poezji [brak początku] - ...sed si praesage ..., k. 238 r. $-238 \mathrm{v}$.

230. Relacja wojny Moskiewskiej, którą Książę Pan wojewoda wileński hetman W. K. L. czynił w Warszawie na seymie roku 1634 mense iulio ${ }^{150}$, k. 238 v. $-247 \mathrm{r}$.

231. List Pana Wołuckiego, kasztelana rawskiego, starosty radomskiego do Zygmunta III dla Króla Polski z 1628 r. ${ }^{151}$, k. 247 r. - 248 r.

232. Kopia listu sunan baszy silistryskiego do Pana kanclerza koronnego ${ }^{152}$, k. 248 r. -248 v.

${ }^{143}$ Zuzanna Chreptowiczówna, córka Jerzego Chreptowicza i Zuzanny z Nonhatrów, poślubiła Tomasza Sapiehę przed 1638 rokiem, Tomasz Sapieha zmarł między 2 a 8 kwietnia 1646 r. Konferencja miała miejsce prawdopodobnie na początku 1638 r., dotyczyła sporu między Krzysztofem Radziwiłłem, wojewodą wileńskim, a Stefanem Pacem, podkanclerzym litewskim (nom. 26 XI 1635 - zm. 17 XI 1640). W konferencji brały udział następujące osoby: wojewoda wileński Krzysztof Radziwiłł, wojewoda smoleński Aleksander Gosiewski (nom. 15 VI 1625 - zm. 1639) oraz pełnomocnicy Stefana Paca: Adam Maciej Maciejowicz Sakowicz, podkomorzy oszmiański (13 IV 1628 - 3 III 1649) oraz Aleksander Sawgowicz, skarbnik wiłkomirski (nom. 3 XII 1635 - zm. 7 II $1660)$.

${ }^{144}$ List do Aleksandra Gosiewskiego, prawdopodobnie autorstwa Adama Sakowicza.

${ }^{145}$ List do podkomorzego oszmiańskiego Adama Sakowicza, prawdopodobnie autorstwa Stefana Paca.

${ }^{146}$ List Aleksandra Sawgowicza, skarbnika wiłkomirskiego.

${ }^{147}$ List do podkomorzego oszmiańskiego Adama Sakowicza.

${ }^{148}$ List do Aleksandra Gosiewskiego, wojewody smoleńskiego.

${ }^{149}$ List do Aleksandra Gosiewskiego, wojewody smoleńskiego.

${ }^{150}$ Relacja z wojny moskiewskiej przedstawiona przez wojewodę wileńskiego Krzysztofa Radziwiłła na sejmie warszawskim dnia 28 lipca 1634 roku.

${ }^{151}$ List Filipa Wołuckiego, kasztelana rawskiego, starosty radomskiego i inowrocławskiego do Zygmunta III, króla polskiego z $1628 \mathrm{r}$.

${ }^{152}$ List sunan baszy silistrijskiego do kanclerza koronnego Stefana Korycińskiego. List ten można $\mathrm{z}$ dużym prawdopodobieństwem datować na listopad $1653 \mathrm{r}$. 
233. Kopia listu marszałka koronnego do kanclerza koronnego ${ }^{153}$, k. 248v. 249r.

234. Kopia listu od chana do Rakoczego z Baru ${ }^{154}$, k. 249 r. - 249 v.

235. Item list chański do hospodara multańskiego [mołdawskiego], sub eadem data 1653 in novembris ${ }^{155}$, k. 249 v. -250 r.

236. Copia responsu kanclerza koronnego Korycińskiego do marszałka wielkiego koronnego Lubomirskiego roku 1653 mensis decembri pod Żwańcem w obozie ${ }^{156}$, k. 250 r. -251 v.

237. Vladislaus $\mathrm{IV}^{157}$, k. 254 r.

238. Elogium Sigismundi III anno 1632 die 30 aprilis mane hora tertia Varsaviae decessit, k. 254 r. -255 v.

239. Aliud elogium: Sigismundus III, k. 255 v. -257 r.

240. Epitaphium Chmielecii P. Kijow, k. 257 r.

241. Epitaphium Lodovici Marillaci Franciae Mareschalli , k. 257 r. - 257 v.

242. Epitaphium exelentissimi herois Joannis Toerassi Galiae mareschalci, k. $257 \mathrm{v} .-258 \mathrm{r}$.

243. VIII Urbanus P. ad Vladislaum IV Poloniae et Sueciae Regem, datum Romae 3 octobris $1643^{158}$, k. 258 r. -258 v.

244. Respons Regiae Maiestatis ad Summum Pontificem, datum Vilnae 1 decembris $1643^{159}$, k. 258 v. -259 r.

245. Littera Casimiri principis ad Serenissimum Poloniae et Sueciae Regem Vladislaum IV, ex Novitatu Romano die 2 iunii $1644^{160}$, k. 259 r. - 260 r.

246. Littera delati obsequii S. R. Maiestatis Poloniae et Sueciae ad Pontificem Innocentium X noviter electum ${ }^{161}$, k. 260 r. - $260 \mathrm{v}$.

247. Urbanus VIII P.P. nobili viro Adamo Kisielio Castellano Czernichoviensi, 3 novembris $1643,{ }^{162} \mathrm{k} .260 \mathrm{v}$.

${ }^{153}$ List marszałka wielkiego koronnego Jerzego Sebastiana Lubomirskiego do kanclerza koronnego Stefana Korycińskiego z listopada $1653 \mathrm{r}$.

${ }^{154}$ List chana krymskiego Islama III Gireja do Jerzego II Rakoczego z Baru także z listopada $1653 \mathrm{r}$

${ }^{155}$ List chana krymskiego Islama III Gireja do hospodara mołdawskiego Jerzego I Stefana $\mathrm{z}$ listopada $1653 \mathrm{r}$.

${ }^{156}$ Datowana na grudzień 1653 r. odpowiedź kanclerza koronnego Stefana Korycińskiego na list $\mathrm{z}$ listopada 1653 r., marszałka wielkiego koronnego Jerzego Lubomirskiego.

${ }^{157}$ Epigramat łaciński.

${ }^{158}$ List papieża Urbana VIII do Władysława IV, króla polskiego datowany: Rzym 3 X 1643 r.

${ }^{159}$ Odpowiedź króla polskiego Władysława IV do papieża Urbana VIII datowany: Wilno 1 XII $1643 \mathrm{r}$.

${ }^{160}$ List królewicza Kazimierza do brata Władysława IV, króla polskiego, datowany Nowicjat Rzymski 2 VI 1644 r.

${ }^{161}$ List Władysława IV, króla polskiego do papieża Innocentego X oddający mu posłuszeństwo niedługo po konklawe 15 IX 1644, koronowany 4 X 1644.

${ }^{162}$ Brewe papieża Urbana VIII do Adama Kisiela, kasztelana czernichowskiego, wzywające Rusinów do jedności z kościołem rzymskim, datowane na 3 XI 1643 r. Brewe o podobnej treści otrzymał metropolita prawosławny Mohyła. 
248. Epitaphium Carolus ${ }^{163}$, k. 261 r. - 262 r.

249. Aliud epitaphium Caroli Stuart ${ }^{164}$, k. 262 r. - 262 v.

250. Carolus Stuart rex Angliae ${ }^{165}$, k. 262 r. - 263 r.

251. Breve pontificum super matrimonium Casimiri Regis Poloniae cum Ludovica Maria, defuncti Vladislai IV fratris relicta vidua Innocentius P.P. X. 20 februarii $1649^{166}$, k. 263 r. - 263 v.

252. Littera Zamosci Generalis Exercitus Ducis et supremi Cancelarii Poloniae ad Summum Pontificem Clementem VIII super matrimonio Sigismundi III cum defunctae uxoris sorore 14 martii $1605^{167}$, k. 263 v. - 264 v.

253. Inscriptio urnae serenissimi principis Sigismundi Casimiri ${ }^{168}$, k. 264 v.

254. Vladislaus IV - inscriptio ${ }^{169}$, k. 264 v. - 265 r.

255. Inscriptio Adami a Kazanow Kazanowski ${ }^{170}$, k. 265 r. - 266 r.

256. Inscripio Christianae Sapieżynae Gembickae, uxoris Christophori Gembicki ${ }^{171}$, k. 266 r.

257. Epitaphium Georgii Ossolinii supremi regni cancelarii subsistite heroes ${ }^{172}$, k. 266 v. -267 r.

258. Copia litterarum archiepiscopi gnesnensis Mathiae Lubiński ad Vladislaum IV Poloniae et Sueciae Regem supra apparatus bellicos contra Turcarum novos $1646^{173}$, k. 267 r. - 267 v.

${ }^{163}$ Łacińskie epitafium poświęcone Karolowi I Stuartowi, królowi angielskiemu (19XI 1600-30 I 1649), który został publicznie ścięty przez Oliwiera Kromwella.

${ }^{164}$ Lacińskie epitafium poświęcone Karolowi Stuartowi, datowane na dzień 10 II 1649 r.

${ }^{165}$ Łacińskie epitafium poświęcone Karolowi Stuartowi.

${ }^{166}$ Brewe papieża Innocentego X do króla polskiego Jana Kazimierza zezwalające na ślub króla z Marią Ludwiką Gonzagą de Nevers, wdową po zmarłym bracie, Władysławie IV, datowane w rękopisie na 20 lutego 1649 roku. Ślub Jana Kazimierza odbył się tego samego roku 31 maja.

${ }^{167}$ List Jana Zamojskiego, kanclerza wielkiego koronnego do papieża Klemensa VIII w sprawie o uzyskanie dyspensy dla Zygmunta III Wazy na jego małżeństwo z arcyksiężniczką Konstancją Habsburżanką, rodzoną siostrą zmarłej żony Anny Habsburżanki, zawarte w tym samym roku 11 grudnia po uzyskaniu dyspensy papieskiej. List w rękopisie datowany jest na 4 III 1605 roku.

${ }^{168}$ Inskrypcja łacińska na urnie z prochami królewicza Zygmunta Kazimierza (1 IV 1640-9 I 1647), syna króla polskiego Władysława IV i Cecylii Renaty. W rękopisie jako datę śmierci podano 9 VIII $1647 \mathrm{r}$.

${ }^{169}$ Inskrypcja łacińska na grobie króla Władysława IV zm. 20 V 1648 roku.

${ }^{170}$ Inskrypcja łacińska Adama Kazanowskiego (ok. 1599-25 XII 1649), kasztelana sandomierskiego, marszałka nadwornego koronnego.

${ }^{171}$ Inskrypcja łacińska Krystyny Sapieżanki Gembickiej, wdowy po Stanisławie Radziejowskim, żony Krzysztofa Gembickiego, krajaczego koronnego, zmarłej 21 września 1650 roku.

${ }^{172}$ Epitafium Jerzego Ossolińskiego ( 15 XII 1595-9 VIII 1650), kanclerza wielkiego koronnego.

${ }^{173}$ List Macieja Łubieńskiego (2 II 1572-28 VIII 1652), prymasa Polski (od 1641r.), do króla polskiego Władysława IV proszący o zaniechanie organizowania nowej wyprawy przeciwko Turkom. W rękopisie list datowany jest na 1546 r. Prawdopodobnie z tego samego okresu, co list następny, to jest z około końca maja $1646 \mathrm{r}$. 
259. Copia litterarum episcopi Cracoviensis ad regem 26 mai $1646^{174}$, k. 267 v. $-268 \mathrm{r}$.

260. Copia litterarum Palatini Cracoviensis Lubomirski ad regem Vladislaum 31 mai $1646^{175}$, k. 268 r. - 269 v.

261. Epitaphium Samueli Lascza na srebrney tablicy ${ }^{176}, 269$ v. -270 r.

262. Lacrimae afflictae Hungariae - epithaphium Georgii Rakocy ${ }^{177}$, k. 270 r.

263. Aliud epithaphium Georgii Rakocy ${ }^{178}$, k. 270 r. - 270 v.

264. Epithaphium Stanislao Stadnicio interempto ${ }^{179}$, k. 270 v.

265. Anthitesis epitaphii ${ }^{180}$, k. 271 r.

266. Rokosz ${ }^{181}$, k. 271 r.

267. Misterium politicum dux cardinalis ${ }^{182}$, k. 271 r. - 271 v.

268. Ioannis Armandi Plessai Richeli S. R. E. Cardinalis eminentissimi, Franciae Ducis potentissimi et regis christianissimi Ludovici XIII ministri famosissimi vitae synopsis inscribenda tumulo $1643^{183}$, k. 272 r. -273 v.

269. Sacris manibus Iohannis Armandi Ducis Richeli ${ }^{184}$, k. 273 v. - 274 r.

270. Piis manibus eiusdem ${ }^{185}$, k. 274 r. - 274 v.

271. [Epitaphium] ${ }^{186}$, k. 275 r. -275 v.

272. Epitaphium ${ }^{187}$, k. 275 v.

273. Pro et contra cardinalem Richelium ${ }^{188}$, k. 275 v.

${ }^{174}$ List Piotra Gembickiego (10 X 1585-14 VII 1657), biskupa krakowskiego (od 10 XI 1642 r.) do króla Władysława IV w sprawie zaciągów wojennych na wojnę przeciwko Turkom, podobnie jak poprzedni nakłaniający króla do rezygnacji z tego pomysłu. List w rękopisie datowany jest na $31 \mathrm{~V}$ $1646 \mathrm{r}$.

${ }^{175}$ List Stanisława Lubomirskiego, wojewody krakowskiego (19 I 1638-16 VI 1649) do króla Władysława IV nakłaniający do rezygnacji z wojny przeciwko Turkom. List datowany w rękopisie na ostatnie dni maja $1646 \mathrm{r}$.

${ }^{176}$ Inskrypcja nagrobna Samuela Łaszcza (ur. ok. 1588, zm. w Krakowie 15 II 1649 r.), strażnika koronnego, głośnego awanturnika i zagończyka, wsławionego między innymi w walkach z Tatarami, Turkami, Kozakami i Szwedami.

${ }^{177}$ Paszkwil w języku łacińskim na Jerzego I Rakoczego, napisany po jego śmierci tj. po $11 \mathrm{X}$ $1648 \mathrm{r}$

${ }^{178}$ Podobnej treści, jak poprzedni, paszkwil na Jerzego I Rakoczego.

${ }^{179}$ Epitafium poświęcone Stanisławowi Stadnickiemu (ok. 1550-10 VIII 1610), uczestnikowi rokoszu zebrzydowskiego w 1606 i 1607 roku.

${ }^{180}$ Paszkwil na Stanisława Stadnickiego w formie antytezy do poprzedniego epitafium pochwalnego.

${ }^{181}$ Epigramat na rokosz. Prawdopodobnie mowa jest o rokoszu Zebrzydowskiego.

${ }^{182}$ Utwór pochwalny (encomium) na cześć kardynała Armanda Jana Duplessis Richelieu (15854 XII 1642).

${ }^{183}$ Inskrypcja nagrobna z 1643 r. opisująca historię życia kardynała Armanda Richelieu.

${ }^{184}$ Anonimowe epitafium poświęcone kardynałowi Richelieu.

${ }^{185}$ Anonimowe epitafium poświęcone kardynałowi Richelieu.

${ }^{186}$ Anonimowy paszkwil w języku fracuskim i łacińskim, stylizowany na psalm błagalny.

${ }^{187}$ Anonimowe epitafium na śmierć kardynała Richelieu.

${ }^{188} \mathrm{Za}$ i przeciwko kardynałowi Richelieu. 
274. Pasquinata Urbani VIII Pontificis ${ }^{189}$, k. 275 v. - 278 r.

275. Divis erinnibus et damnatae memoriae Urbani Pontificis ${ }^{190}$, k. 278 r. - 279 r. 276. Coloquium ${ }^{191}$, k. 279 r. - 279 v.

277. Hugo Grotius Jacobo Laurentii ${ }^{192}$, k. 279 v. -280 r.

278. Ex litteris N. N. Londini 11 aprilis datis ${ }^{193}$, k. 280 r.

279. Epitaphium Renatae Ceciliae Polonorum reginae ${ }^{194}$, k. 280 r. - 280 v.

280. Inscriptio tumuli eiusdem ${ }^{195}$, k. $280 \mathrm{v}$.

281. Epitaphium Elisabethae, reginae Angliae ${ }^{196}$, k. 281 r.

282. Epitaphium Mariae Stuartae, Scotorum reginae ${ }^{197}$, k. 281 r. - 281 v.

283. In eandem ${ }^{198}$, k. $281 \mathrm{v}$.

284. Epithaphium King John's ${ }^{199}$, k. 281 v. - 282 r.

285. Henrici II Angliae regis ${ }^{200}$, k. 282 r.

286. Simonis Montfort ${ }^{201}$, k. 282 r.

287. Edvardi I Angliae Regis ${ }^{202}$, k. 282 r.

288. Epitaphium Isaaci Casauboni ${ }^{203}$, k. 282 r.

289. Epithaphium Cambdeni ${ }^{204}$, k. 282 v.

290. In margine monumenti Casauboni ${ }^{205}, \mathrm{k} .282 \mathrm{v}$.

291. Nicolao Copernico Toruniensi ${ }^{206}$, k. 282 v.

${ }^{189}$ Paszkwil na papieża Urbana VIII napisany na początku 1643 roku piętnujący jego poczynania polityczne nepotyzm. Urban VIII nadał bowiem swoim trzem synowcom godności kardynalskie, wysokie urzędy i majątki.

${ }^{190}$ Podobnej treści, jak powyższy utwór, paszkwil na papieża Urbana VIII, prawdopodobnie autorem obu jest nieznany bliżej poeta Pasquinus Morphorius, podpisany pod drugim utworem.

${ }^{191}$ Utwór polityczny o charakterze satyrycznym obrazujący politykę wszystkich władców europejskich w końcowym okresie wojny trzydziestoletniej.

${ }^{192}$ List Hugona Grotiusa (1583-1645) do Jakuba Laurentiusa, pisany w maju 1642 r.

${ }^{193}$ Fragment listu anonimowego autora pisany w Londynie 11 kwietnia, brak daty rocznej.

${ }^{194}$ Epitafium na cześć Cecylii Renaty, królowej polskiej, żony Władysława IV, zmarłej 24 III 1644 roku.

${ }^{195}$ Inskrypcja na grobie Cecylii Renaty w katedrze na Wawelu.

${ }^{196}$ Epitafium poświęcone Elżbiecie I Tudor (7 IX 1533-24 III 1603), królowej angielskiej.

${ }^{197}$ Inskrypcja nagrobna Marii I Stuart, królowej Szkocji (8 XII 1542-8 II 1587), ściętej na rozkaz Elżbiety I, królowej angielskiej.

${ }^{198}$ Epitafium na cześć Marii I Stuart.

${ }^{199}$ Epitafium poświęcone Janowi Bez Ziemi, królowi Anglii (1167-1216).

${ }^{200}$ Epitafium poświęcone Henrykowi II Plantagenetowi, królowi Anglii (1133-1189).

${ }^{201}$ Epitafium poświęcone Szymonowi V z Monfort (1208-1265), przywódcy buntu możnowładców przeciwko królowi Anglii, Henrykowi III Plantagenetowi.

${ }^{202}$ Epitafium poświęcone Edwardowi I (1239-1307), królowi Anglii.

${ }^{203}$ Epitafium poświęcone Isaakowi Casabonowi (1559-1614), jednemu z najwybitniejszych filologów klasycznych i teologa.

${ }^{204}$ Epitafium poświęcone Wilhelmowi Cambden. Wilhelm Cambden zmarł, jak podaje kopista,

9 XI 1628, mając lat 47.

${ }^{205}$ Inskrypcja na grobie Izaaka Casaubona.

${ }^{206}$ Epitafium na cześć Mikołaja Kopernika (19 II 1473-24 V 1543). 
292. Epitaphium Johanni Oveni Poetae Cambro-Britanni ${ }^{207}$, k. 282 v.

293. Ossa Stanislai in Żurow in Olesko, Terrarum Russiae Palatinidis ${ }^{208}$, k. 282 v. $-283 \mathrm{r}$.

294. Encomium Georgii Ossolinii ${ }^{209}$, k. 283 r. - 283 v.

295. Cippus unionis et liga ${ }^{210}$, k. 283 v. - 285 r.

296. Examen rationum qua pro et contra regis Poloniae Vladislai IV cum principe palatina matrimonium adferuntur ${ }^{211}, \mathrm{k} .285 \mathrm{r} .-287 \mathrm{v}$.

297. Carapha Palliani dux cum strangulato anno 1561 die 6 martii, fratre cardinali ipse etiam eiusdem diei vespere decollandus esset sequentia monita ad filium suum unigenitum e castro Angeli missit ${ }^{212}$, k. 288 r. - 288 v.

298. Clepsydra Anglicanae monarchiae evoluta sive tragica mors Magnae Britanniae regis Caroli I 9 februarii 1649 Casparis Erffeni Coloniae Agrippinae $1649^{213}$, k. 289 r. - 290 v.

299. Copia litterarum Islangierey Chani Tattarorum ad Serenissimum olim regem Poloniae Vladislaum IV ${ }^{214}$, k. 290 v. - 291 r.

${ }^{207}$ Epitafium na cześć Jana Owena (zm. 1622), poety nowołacińskiego kambryjsko-brytyjskiego, znanego głównie z twórczości epigramatycznej (Epigramatum libri X, Londini 1612). Być może niektóre epigramaty tutaj zamieszczone są jego autorstwa.

${ }^{208}$ Inskrypcja nagrobna Stanisława Daniłowicza (w rękopisie nie podano nazwiska), syna Jana, wojewody ruskiego (tytułowanego w rękopisie wojewodą ruskim), starosty korsuńskiego i czehryńskiegio, który w potyczce z Tatarami w 1636 został wzięty do niewoli i ścięty w namiocie Murzy Kantemira. W rękopisie podano datę śmierci Stanisława na dzień 7 XI 1636 roku. Miał wtedy zaledwie 25 lat. Na nim wygasł ród Daniłowiczów, a spadkobierczynią dóbr została siostra Stanisława Teofila, którą poślubił Jakub Sobieski. Nagrobek z tą inskrypcją znajdował się prawdopodobnie w Olesku.

${ }^{209}$ Utwór pochwalny na cześć Jerzego Ossolińskiego, kanclerza wielkiego koronnego (15 XII 1595-9 VIII 1650), wiersz powstał w okresie, gdy Ossoliński był podkanclerzym koronnym (20 III 1638-28 II 1643).

${ }^{210}$ Nagrobek Unii i Ligi. Utwór polityczny piętnujący Unię i Ligę. Datę owej rzekomej śmierci unii i ligi podano na kwiecień 1621r., a czas trwania związków na 13 lat, 3 miesiące i 5 dni. Unia Protestancka powstała w maju 1608 roku, Liga Katolicka powstała w 1609 roku.

${ }^{211}$ Racje za i przeciw zawarciu małżeństwa przez Władysława IV z Elżbietą, córka Fryderyka, palatyna Renu, króla czeskiego. Księżniczkę nazywano Angielką, gdyż matką jej była córka Jakuba VI, a siostra Karola I. Sprawa była kontrowersyjna z racji wyznania protestanckiego kandydatki. Od marca do grudnia 1635 roku trwały szerokie dyskusje i zebrania senatu (marzec 1635), a później w sejmie (listopad 1635) w sprawie poślubienia palatynówny. Ostatecznie jednak z powodu wielu sprzeciwów, król poślubił Cecylię Renatę, córkę cesarza Ferdynanda II.

${ }^{212}$ List księcia Giovanniego Carafy di Palliano do swego syna, napisany na chwilę przed śmiercią, ściętego 6 III 1561, straconego wraz ze swym bratem, kardynałem Carlem Carafą przez papieża Piusa IV, jego następca, papież Pius V zrehabilitował rodzinę Carafów 26 IX 1567 uznając wyrok za niesprawiedliwy.

${ }^{213}$ Wypis z książki Caspara Erffenusa, (wydanej: Coloniae Agrippinae 1649) na temat stracenia Karola I, króla angielskiego.

${ }^{214}$ List chana tatarskiego Islama III Gireja do króla polskiego Władysława IV z żądaniem płacenia trybutu z około 1648 roku. 
300. Copia litterarum a senatu ad illustrem principium D. Mussan Bassam serenissimi et potentissimi Turcarum imperatoris supremum vesirum 26 Iunii $1648^{215}$, k. 291 r. -291 v.

301. Ad legatum Galiae 26 iunii $1648^{216}$, k. 291 v. - 292 r.

302. Copia litterarum Christinae, Suevorum Gothorum, Vandalorum Reginae Vladislao IV regi fratri Stocholmi octobris $1646^{217}$, k. 292 r. - 292 v.

303. Vladislaus IV Christinae, Suevorum Gothorum, Vandalorum Reginae 17 decembris $1646^{218}$, k. $292 \mathrm{v}$.

304. Interventio Reginae Sueciae apud Imperatorem Romanum pro Statibus August. Confesioni addictis in inferiori Austria degentibus 26 martii $1653^{219}$, k. 293 r. -294 r.

305. Copia litterarum Joannis Casimiri Regis Poloniae ad Imperatorum Romanum Ferdinandum III anno 1653 ultimae iulii Leopoli ${ }^{220}$, k. 294 r. - 294 v.

306. Sacra caesarea maiestas ${ }^{221}$, k. 294 v.

307. Pacta pacis inter regem Poloniae et imperatorem Turcarum tradita legato magno imperatoris, Varsaviae d. 2 septembris $1640^{222}$, k. 294 v. - 296 v.

308. Delineatio foederis inter reges Galiae et Poloniae ${ }^{223}$, k. 296 v. - 297 r.

309. Exequiarum Annae principis Sueciae brevis descriptio 16 iulii $1636^{224}$, k. 297 r. -298 r. $\mathrm{ku}$.

${ }^{215}$ List senatu polskiego do wielkiego wezyra Mussan Baszy, dany Warszawa 26 VI 1648 ro-

${ }^{216}$ List prawdopodobnie senatu polskiego do legata francuskiego, dany Warszawa 26 VI 1648 r.

${ }^{217}$ List Krystyny, królowej Szwecji, do króla polskiego Władysława IV, dany w Sztokholmie w październiku $1646 \mathrm{r}$.

${ }^{218}$ List króla Władysława IV do królowej Szwecji Krystyny, dany w Warszawie 17 XII 1646 r.

${ }^{219}$ Interwencja królowej Szwecji Krystyny u cesarza rzymskiego Ferdynanda III w sprawie stanów Austrii mniejszej, dana w Sztokholmie 26 III 1653 roku.

${ }^{220}$ List Jana Kazimierza, króla polskiego do cesarza Ferdynanda III, dany w Warszawie dnia 31

VII $1653 \mathrm{r}$.

${ }^{221}$ Prawdopodobnie również jest to fragment listu Jana Kazimierza do Ferdynanda III.

${ }^{222}$ Warunki pokoju między królem polskim a sułtanem tureckim przekazane legatowi sułtana $\mathrm{w}$ Warszawie dnia 2 IX 1640 r., tj. po powrocie z poselstwa (trwającego od lutego do 7 VII 1640) do Konstantynopola Wojciecha Miaskowskiego, podkomorzego lwowskiego, który zdołał uwolnić i wykupić 130 z galer jeńców, zawarł z sułtanem Ibrahimem porozumienie w sprawie obustronnego handlu i powstrzymywaniu napadów Kozaków na Turcję, a Tatarów na Polskę.

${ }^{223}$ Określenie przymierza między królem francuskim i polskim i między oboma królestwami, bez daty. Chodzi tu prawdopodobnie traktat Polski z Francją zawarty przez króla Władysława IV w grudniu 1635 .

${ }^{224}$ Opis uroczystości pogrzebowych królewny Anny Wazówny (17 V 1568-26 II 1625). Pierwotnie została pochowana w Brodnicy, gdyż jako protestantka nie mogła spocząć na Wawelu. Okazały pogrzeb wyprawił jej bratanek Władysław IV, dnia 16 VII 1636 r. przenosząc jej szczątki z Brodnicy do Torunia, do mauzoleum zbudowanego przy kościele Najświętszej Marii Panny. W imieniu króla występowali podczas uroczystości wojewoda wileński Krzysztof Radziwiłł, starosta sztumski Zygmunt Guldenstern oraz starosta libiszowski Andrzej Rej (wnuk sławnego pisarza Mikołaja Reja). Wszyscy oni byli protestantami, a pogrzeb zgromadził przedstawicieli religii reformowanej z całego kraju. Wśród nich Potockich, Leszczyńskich, Ostrorogów. Byli też goście zagranicz- 
310. Ioannes de Torres, archiepiscopus Adrianopolis, nutius apostolicus Innocentii X Papae ad serenissimum Joannem Casimirum Poloniae et Sueciae regem die 5 martii $1650^{225}$, k. 298 r.

311. Inscriptio Tumulus Patris Josephi Capucini Contessarii Ludovici XIII regis Galliarum, $1639^{226}$, k. 1639, k. 298 v. - 299 r.

312. Siste vomere'm verrucane arator ${ }^{227}$, k. 299 r. - 299 v.

313. D.O.M. ${ }^{228}$.

314. Pacta dotalia inter Vladislaum IV Poloniae et Suecia Regem et Lodovicam Mariam Gonzagam Niverniae ducissam ${ }^{229}$, k. 299 v. - 300 r.

315. Copia litterarum Domini Felberi ad D. Oelhaffium de morbo et excessu serenissimi ac potentissimi principis D.D.Wladislai IV D. G. Poloniae et Sueciae regis defuncti Mereczi ${ }^{230}$, k. 300 r. - $301 \mathrm{v}$.

316. Magister Evaldus Rlowen Consulatus Stetiniensis protonotarius ${ }^{231}$, k. 301v $-302 \mathrm{r}$.

317. Copia litterarum archiepiscopi Strigoniensis Georgii Lippa ad V[ice] C[ancelarium]. R[egni] Poloniae ${ }^{232}$, k. 302 r. - 302 v.

ni, piastowscy książęta Legnicy oraz Brzegu i niemiecki książę Anhaltu. W sumie kilka tysięcy uczestników. Uroczystość stała się manifestacją innowierców polskich przeciwko rosnącej nietolerancji i kontrreformacji. Trumnę królewny złożono w krypcie nakrytej marmurowym sarkofagiem.

${ }^{225}$ List Jana de Torres, arcybiskupa Adrianopolis, nuncjusz papieża Innocentego X w Polsce, do króla Jana Kazimierza, z dnia 5 III 1650.

${ }^{226}$ Paszkwil w języku łacińskim z 1639 roku, na zmarłego w wieku 64 lat kapucyna Józefa du Tremblay z Paryża, doradcy króla francuskiego Ludwika XIII, pomocnika kardynała Armanda Richellieu. Ten słynny kapucyn kierował niemiecką polityką Francji, chciał wielkiej krucjaty przeciwko Turkom, osłabienia potęgi cesarza niemieckiego i dominacji Francji w Europie. W tym utworze krytykowane są jego intrygi, surowość i bezwzględność.

${ }^{227}$ Epitafium łacińskie poświęcone prawdopodobnie Don Francisco de Melo, dowódcy armii hiszpańskiej w czasach wojny trzydziestoletniej. Utwór sławi jego zwycięstwo nad armią francuską i opłakuje późniejszy upadek Hiszpanii.

${ }^{228}$ Inskrypcja łacińska potwierdzająca fundację klasztoru i kolegium pijarów w Podolińcu na Spiszu uczynionej przez Stanisława Lubomirskiego, wojewodę krakowskiego w 1643.

${ }^{229}$ Ślub Władysława IV z Ludwiką Marią odbył się 5 XI 1645 per procura, Władysława zastępował wtedy brat jego Jan Kazimierz, właściwy ślub odbył się 10 marca 1646. Akty ślubne zostały podpisane w Fontainebleau 26 IX 1645. Druk (w j. francuskim): M. Dogiel, Codex diplomaticus Regni Poloniae et Magni Ducatus Lituaniae, t. 1, Vilnae 1758, s. 469-473.

${ }^{230}$ Relacja medyka królewskiego Felbera o chorobie i śmierci króla Władysława IV, przedstawiona w Mereczu 15, 20, 21 maja 1648 roku. Obecnie podaje się, że król zmarł prawdopodobnie z powodu przedawkowania środków na przeczyszczenie.

${ }^{231}$ Magister Evaldus Rlowen, protonotariusz rady miejskiej w Szczecinie opisuje ślub Bolesława X, księcia pomorskiego z Anną, córką Kazimierza IV Jagiellończyka (w rękopisie na marginesie podano błędnie Kazimierza III), króla polskiego, który miał miejsce w Szczecinie 2 II 1491 (w rękopisie błędnie 2 II 1484). Opisuje to wydarzenie M. Kromer, De origine et rebus gestis Polonorum ks. 29, Basileae 1551(było też wydanie późniejsze: Coloniae 1589), s. 461.

${ }^{232}$ List Jerzego Lippaya, arcybiskupa strygońskiego do podkanclerzego wielkiego koronnego Andrzeja Leszczyńskiego, biskupa kamieńskiego (nom. II 1645-8 XII 1650) z dnia 27 III 1645 roku. 
318. Regis Stephani allocutio ad Ordines regni et continuo illius ${ }^{233}$, k. 302 v. $-303 r$.

319. Burgrabiatus Varsaviensis Generoso Stephano Schroeter. Datum Varsaviae in conventu regni generali die 20 iulii anno $1643^{234}$, k. 303 r.

320. Joannes Casimirus Generoso Stephani Schroeter ${ }^{235}$, k. 304 r.

321. Denunciatio belli per regem Galiae Carolo Quinto Imperatore anno $1526^{236}$, k. 304 r. $-304 \mathrm{v}$.

322. Instructio Dominis legatis episcopo Varmiense et palatino Posnanense in Galliam ad deductionem Sponsae reginalis ituris data Varsaviae $1645^{237}$, k. 304 v. -305 v.

323. Instructio ad serenissimam principem Dominam Suevorum Reginam etc. a serenissimo et potentissimo rege Johanne Casimiro rege Poloniae M. D. L. etc. eius internuncio et aulice generoso Mathiae Krokowski, data Warsavi$a^{238}$, k. 305 v. -306 r.

324. Formula abiurationis haeresium apud Pontificios usitata Pius V'239, k. 306 r.

325. Supplica P. Radziejowskiego ${ }^{240}, 306 \mathrm{v}$.

326. Interessio Reginae Sueciae Christinae pro vice cancelario anno $1654^{241}$, k. $306 \mathrm{v}$.

${ }^{233}$ Przemówienie Stefana Batorego do Stanów Królestwa, bez daty.

${ }^{234}$ Władysław IV, król polski, nadaje urząd burgrabiego miasta Warszawy urodzonemu Stefanowi Schroeterowi w dowód i podzięce za zasługi wojenne. Odpis dokumentu danego w Warszawie dnia 20 VII 1643 roku. Podpisani byli na nim król Władysław IV i Jan Gembicki, sekretarz wielki koronny.

${ }^{235}$ Jan Kazimierz, król polski, potwierdza, ratyfikuje nadanie urzędu burgrabiego miasta Warszawy Stefanowi Schroeterowi przez Władysława IV. Odpis dokumentu danego w Warszawie, bez daty.

${ }^{236}$ Wypowiedzenie wojny przez króla francuskiego Franciszka I Walezjusza cesarzowi rzymsko-niemieckiemu Karolowi V Habsburgowi w roku 1526.

${ }^{237}$ Instrukcja dla Wacława Leszczyńskiego, biskupa warmińskiego i Krzysztofa Opalińskiego, wojewody poznańskiego, posłujących do Francji po odebranie narzeczonej Władysława IV, Marii Ludwiki Gonzagi, jesienią 1645 r.

${ }^{238}$ Odpis instrukcji danej przez Jana Kazimierza, króla polskiego Maciejowi Krokowskiemu, udającemu się w poselstwo do królowej szwedzkiej Krystyny z prośbą o utrzymanie pokoju. Bez daty, prawdopodobnie z okresu rokowań pokojowych polsko-szwedzkich w $1652 \mathrm{r}$.

${ }^{239}$ Brak tekstu, na następnej stronie już inny tekst innego kopisty.

${ }^{240}$ Suplika, czyli prośba Hieronima Radziejowskiego do króla Jana Kazimierza o ułaskawienie i uchylenie banicji oraz infamii z okresu, gdy przebywał na wygnaniu, prawdopodobnie będąc już w Szwecji. Jako że do Sztokholmu przybył 1 V 1652, być może jest to list z 20 VII 1652, kiedy to Radziejowski wysłał szereg listów do Polski oraz swój manifest niewinności. Może to być również suplika późniejsza z 1654 r., ale sądząc z następnego listu, królowej Krystyny do Jana Kazimierza oba te listy są z lipca 1652 r.

${ }^{241}$ List królowej szwedzkiej Krystyny do Jana Kazimierza z prośbą o przywrócenie do wszelkich łask Hieronima Radziejowskiego przywieziony przez agenta szwedzkiego Jana Kocha. Koch przywiózł też listy od Radziejowskiego z dnia 20 VII 1652, dotarły one jednak już po sejmie i po konstytucji Poena perduellionis na Hieronimie Radziejowskim przeszłym podkanclerzym koronnym uznającej go zdrajcą ojczyzny i wieczystym infamisem z dnia 17 VIII 1652. List poprzedni 
327. Votum Pana podskarbiego Koronnego ${ }^{242}$, k. 307 r. - 310 v.

328. Porządek Kawalkatii Cesarza Ottomańskiego Sołtan Mechmeta do meczetu na Nabożeństwo w dzień nasz Wielgopiątkowy 3 aprilis $1654^{243}$, k. 310 v. $-312 \mathrm{r}$.

329. Kopia listu cara moskiewskiego do księcia Kurlandzkiego 23 Maii $1654^{244}$, k. 312 r. -313 r.

330. Respons a Duce Curlandiae Magno Domino caesari et Magno Duci Alexei Michaelowi etc. 26 iunii $1654^{245}$, k. $313 \mathrm{v}$.

331. Copia listu od chana krymskiego do K. J. M. in iulio $1654^{246}$, k. 313 v. $-314 \mathrm{v}$.

332. Epitaphium Carolo duci Lotharingiae ${ }^{247}$, k. 314 v. - 315 r.

333. Aliud [epitaphium Carolo duci Lotharingiae] ${ }^{248}$, k. 315 r.

334. [Epitaphium Ferdinandi IV] posuit J. W. P. ab Aurspergle ${ }^{249}$, k. 315 r. $-315 \mathrm{v}$.

335. Aliud [Epitaphium Ferdinandi IV] ${ }^{250}$, k. 315 v.- 316 v.

Radziejowskiego jest też prawdopodobnie z tego samego czasu. W rękopisie jest błędna data 1654, Koch przybył z listem od królowej Krystyny w 1652.

${ }^{242}$ Wotum na sejmie Bogusława Leszczyńskiego, podskarbiego wielkiego koronnego, prawdopodobnie na drugim sejmie, latem 1654, gdzie burzliwie sprawdzano rachunki po stwierdzeniu wielkiego zadłużenia i gdzie Bogusław Leszczyński bronił się tłumacząc, że podatki nie są ściągane należycie. Tematyka mowy - brak pieniędzy na wojsko.

${ }^{243}$ Opis orszaku sułtana Mehmeda IV udającego się do Meczetu Szacherade dnia 3 IV 1654 r., przedstawiony przez polskiego posła, który uzyskal pozwolenie na patrzenie na ów orszak. Jest to prawdopodobnie relacja Mariusza Stanisława Jaskólskiego, posła Jana Kazimierza na Krym, barwny opis tej legacji przedstawił kanclerzowi koronnemu Korycińskiemu i hetmanowi wielkiemu koronnemu „Rewerze” Potockiemu na początku maja $1654 \mathrm{r}$. W czasie tego poselstwa widział więc nie tylko chana tatarskiego ale też sułtana tureckiego.

${ }^{244}$ Odpis polskiego przekładu listu cara moskiewskiego Aleksego I Romanowa do księcia Kurlandii Jakuba Kettlera (28 X 1610-1 I 1682) z dnia 23 V 1654.

${ }^{245}$ Odpowiedź księcia kurlandzkiego Jakub Kettlera na powyższy list cara moskiewskiego $\mathrm{z}$ Mitawy z dnia 26 VI 1654 w polskim przekładzie. Jako autorzy przekładu obu listów w rękopisie podani są Samuel Twardowski ze Skrzypna i Aleksander Gorczyn.

${ }^{246}$ Przekład polski listu chana krymskiego Islama III Gireja podanego przez Sulejmana Agę do Jana Kazimierza z lipca 1654 r., w którym chan składa ofertę wspólnej wyprawy przeciwko Rosji i Kozakom. Podczas sejmu 20 VII 1654 król, prymas i marszałek izby poselskiej zaprzysięgli przymierze wobec Sulejmana Agi.

${ }^{247}$ Epitafium w języku łacińskim Karola IV Lotaryńskiego (1604-1675), jest to pozorne epitafium opłakujące położenie księcia, jak podano w rękopisie na marginesie: pojmanego i żyjącego dotąd - epitafium Lotharingico captivo et superstiti adhunc, co wskazuje datę ostatnich zapisków w kodeksie na lata 1670-1675, kiedy księstwo było okupowane przez Francuzów, a książę przebywał w niewoli.

${ }^{248}$ Podobnie pozorne epitafium Karola IV Lotaryńskiego, z tego samego czasu.

${ }^{249}$ Epitafium Ferdynanda IV Habsburga (8 IX 1633-9 VII 1654), najstarszego syna i koregenta cesarza Ferdynanda III Habsburga.

${ }^{250}$ Inne epitafium Ferdynanda IV. 
336. Epitaphium Reginae Scotiae Mariae decollatae ${ }^{251}$, k. 316 v.

337. Copia litterarum Regis Poloniae ad Sueciae Regem ${ }^{252}$, k. 316 v. - 317 r.

338. Visio Domini de Chalandio Praesidis in Parlamento Parisiensi, viri magni nominis et pontificii quam hoc anno 1654 habuit et in qua sequentes versiculos ab angelo in Tabula ostensos vidit descriptum 22 septembris $1654^{253}$, k. $317 \mathrm{r}$.

339. In Risselium Cardinalem ${ }^{254}$, k. 317 v. - 318 r.

\section{Indeks osób i miejscowości do inwentarza sylwy}

(liczby stanowią numery porządkowe dokumentów wpisanych do księgi)

Aleksy I Romanow, car moskiewski 329, 330

Anna Wazówna, królewna szwedzka 309

Anna Katarzyna Konstancja Wazówna, królewna polska 195

Bar 234

Batoh 114, 166, 167

Bolestraszycki Samuel 5

Bukowiec 23

Caraffa (Carapha) Carlo 297

Carafa (Carapha) Giovanni 297

Cambden Wilhelm 289

Casaubon Isaak 288, 290

Cat Jacobus 116

Cecylia Renata, królowa polska 279, 280

Chalandius [N.] 338

Chmielnicki Bohdan hetman kozacki 3, 4, 113, 114, 157, 166, 167, 240

Chrząstowska Jadwiga z Gosławskich 7

Cikowski Stanisław 13, 14

Daniłowicz Stanisław 293

Desportes Phillippe 169, 170

Dorohostajska Elżbieta 198-201

Dorohostajski Władysław 198-201

Dragocki Maciej 212

Elblatg 118-121

Elżbieta I Tudor, królowa angielska 281

Elżbieta, palatynówna reńska 296

Erffenus Caspar 298

${ }^{251}$ Epitafium Marii I Stuart, królowej Szkocji (8 XII 1542-8 II 1587), ściętej na rozkaz Elżbiety I, królowej angielskiej.

${ }^{252}$ Fragment listu Jana Kazimierza, króla polskiego do Karola X Gustawa, króla szwedzkiego, prawdopodobnie z $1654 \mathrm{r}$.

${ }^{253}$ Przepowiednia niejakiego Chalandinusa przedstawiona w parlamencie paryskim w $1654 \mathrm{r}$., spisana tego samego roku 22 września.

${ }^{254}$ Epigramat krytykujący rządy kardynała Armanda Richelieu. 
Felberus [N.] 315

Ferdynand II, cesarz rzymsko-niemiecki 178

Ferdynand III cesarz rzymsko-niemiecki 304-306

Ferdynand IV cesarz konregent rzymsko-niemiecki 334, 335

Firlej Andrzej 25

Firlej Dorota z Leśniowolskich 22

Firlej Mikołaj 25

Firlej Stanisław 22

Franciszek I Walezjusz, król francuski 321

Gembicka Krystyna z Sapiehów 256

Gembicki Krzysztof 256

Gembicki Piotr 259

Gorczyn Aleksander 330

Gosiewski Aleksander 221-223, 226-228

Gratianus Martius 141, 143

Grotius Hugo 277

Gruszewski Jerzy 215, 216

Gustaw II Adolf, król szwedzki 100, 111, 112, 162, 164, 173, 174

Henning Maria 118

Henryk II , król angielski 285

Innocenty X, papież 246, 251, 310

Islam III Girej, chan krymski 234, 235, 299, 331

Jakub Kettler, książę kurlandzki 329, 330

Jakub I Stuart, król angielski vel Jakub VI król szkocki 164

Jan Bez Ziemi, król angielski 284

Jan Kazimierz, król polski 2, 33, 34, 97, 113-115, 117, 166, 194, 243-245, 251, $305,306,310,320,323,325,326,331,337$

Jan Olbracht, król polski 26

Jaskólski Stanisław 328

Jerzy I Stefan, hospodar mołdawski 235

Kallimach Filip 26

Kamieniec Podolski 3, 4, 117

Kalinowski Mikołaj 114, 166, 167

Karol I Stuart, król angielski 175, 248-250, 298

Karol IV, książę Lotaryngii 332, 333

Karol V Habsburg, cesarz rzymsko-niemiecki 321

Karol X Gustaw, król szwedzki 337

Kazanowski Adam 215, 255

Kisiel Adam 247

Klemens VIII, papież 252

Kobierzycki Stanisław 34

Kochanowski Jan 169, 171

Kochlewski Piotr 9, 198-201

Konstancja z Habsburgów, królowa polska 252

Kopernik Mikołaj 291 
Koryciński Stefan 232, 2333, 236

Kossakowski Mikołaj 9

Krokowski Maciej 323

Krystyna Wazówna, królowa szwedzka 115, 157, 158, 302-304, 323, 326

Kurosz Jadwiga z Greków 20

Kurosz Stanisław 20

Laud Wilhelm 177

Laurentius Jacobus 277

Leszczyński Andrzej 11, 317

Leszczyński Bogusław 327

Leszczyński Rafał 201

Leszczyński Wacław 322

Lippay Jerzy 317

Lubomirski Jerzy Sebastian 233, 236

Lubomirski Stanisław 219, 260

Ludwika Maria Gonzaga de Nevers, królowa polska 251, 314, 322

Łaszcz Samuel 261

Łazińska Barbara ze Schlichtingów 23

Łaziński Władysław 23

Łubiński Maciej 258

Maria I Stuart 282, 283, 336

Marillac Ludwik 241

Mehmed IV 328

Melo Franciszek, de 312

Merecz 315

Morsztyn Krzysztof 12

Moskorzowski Andrzej 7, 12, 14, 21, 23

Moulins Piotr, de 5

Mussan Basza 300

Mylius Michael 118

Naborowski Daniel 201

Nigrinus Bartolomeus 182

Nowodworski Bartłomiej 10

Oelhafius [N.] 315

Opaliński Krzysztof 2, 322

Opatów 29

Ossoliński Jerzy 13, 14, 27, 29, 101, 106-110, 126-128, 257, 294

Otwinowska Elżbieta z Wierzbiętów 17, 18

Otwinowski Walerian 17, 18

Owen Joannes 292

Pac Stefan 221, 222, 223

Paryż 338

Paweł V, papież 31

Podbereska [N.] 199

Podoliniec 313 
Potocka Anna z Leszczyńskich 168

Potocki Jan Teodoryk 168

Potocki „Rewera” Stanisław 167

Pruński Aleksander Oktawian 11

Przyjemski Stanisław 220

Przypkowski Samuel 20, 126-128

Radostów 21

Radziejowski Hieronim 1, 115, 157-160, 325, 326

Radziwiłł Albrycht Stanisław 202, 206, 208

Radziwiłł Aleksander 186

Radziwiłł Bogusław 190

Radziwiłł Janusz 105, 204

Radziwiłł Jerzy 172

Radziwiłł Krzysztof 110, 172, 190-197, 202, 205-209, 211-228, 230

Radziwiłłowa Tekla z Wołłowiczów 186

Radziwiłłowie 211, 212, 213

Rakoczy I Jerzy, książę Siedmiogrodu 262, 263

Rakoczy II Jerzy, książę Siedmiogrodu 234

Richelieu Armand Jan Duplessis 267-273, 339

Richterus Godofredus 120, 121

Rlowen Evaldus 316

Rzeczyce 2

Rzemianowice 23

Sakowicz Adam 221-223

Sapiecha Lew 100

Sawgowicz Aleksander 221, 224

Schlichting Jonasz 23

Schroeter Stefan 319, 320

Sicercius Franciscus 130-134

Sieniuta Jadwiga z Wilamów 21

Sieniuta Piotr 21

Sirenberg Konstancja 173

Siyliagya Beniamin 147

Skytte Joannes 164

Smoleńsk 203

Sobieski Jakub 8, 10

Stadnicki Stanisław 264

Stefan Batory, król polski 137, 318

Szyszkowski Marcin 100

Toeressius Joannes 242

Torres Joannes, de 310

Torun 180

Tremblay Joseph, du 311

Tryzna Marcjan 216

Twardowski Samuel 330 
Urban VIII, papież 109, 243, 244, 247, 274, 275

Vossius Gerardus 147

Wallenstein Albrecht Wenzel, książę Friedlandu 183

Warszawa 5, 6, 191-197, 230

Wenecja 31

Wężyk Jan 218

Wielopolski Jan 33

Wiesiołowski Krzysztof 186

Wilno 203

Władysław IV 29, 35, 106-110, 161, 193, 194, 196, 203-205, 207, 214, 217, 237 , 243-247, 254, 258-260, 296, 299, 302, 303, 307, 308, 314, 315, 319

Wołucki Filip 231

Wujek Jakub 142

Wyhowski Iwan 158

Zamojski Jan 252

Zasławski Władysław Dominik 160

Zbaraski Jerzy 8, 100

Zborowski Andrzej 15

Zborowski Samuel 15

Zebrzydowski Mikołaj 26, 28

Zygmunt III Waza, król polski 5, 135, 145, 209, 231, 238, 239, 252

Zygmunt Kazimierz Waza, królewicz polski 253

Żwaniec 236

\section{Bibliografia}

Augustyniak U., Dwór i klientela Krzysztofa Radziwitła (1585-1640). Mechanizmy patronatu, Warszawa 2001.

Bartoszewicz K., Radziwiłtowie, Warszawa-Kraków 1927.

Bibliografia Literatury Polskiej. Nowy Korbut. Piśmiennictwo staropolskie, red. R. Pollak, t. 1-3, Warszawa 1963-1965.

Boniecki A., Herbarz Polski, t. 1-12, Warszawa 1899-1908.

Czapliński W., Polska a Prusy i Brandenburgia za Władysława IV, Wrocław 1947.

Czapliński W., Władystaw IV i jego czasy, Warszawa 1976.

Chmaj L., Samuel Przypkowski na tle prądów religijnych XVII wieku, Kraków 1927.

Dogiel M., Codex diplomaticus Regni Poloniae et Magni Ducatus Lituaniae, t. 1, Vilnae 1758, s. 469-473.

Dworzaczek W., Genealogia, Warszawa 1959.

Grabowski T., Literatura ariańska w Polsce 1560-1660, Kraków 1908.

Grabowski T., Literatura luterska w Polsce wieku XVI 1530-1630, Poznań 1920.

Grabowski T., Z dziejów literatury kalwińskiej w Polsce 1550-1650, Kraków 1906. 
Kossowski A., Protestantyzm $w$ Lublinie $i$ w Lubelskiem $w$ XVI-XVII w., Lublin 1933.

Księcia Krzysztofa Radziwilta hetmana polnego Wielkiego Księstwa Litewskiego sprawy wojenne i polityczne 1621-1632, Paryż 1859.

Krasiński W., Zarys dziejów powstania i upadku reformacji w Polsce, t. 1-3, Warszawa 1903-1905.

Laucevicius E., Popierius Lietuvoje XV-XVIII a, Vilnius 1967.

Listy Wtadystawa IV do Krzysztofa Radziwita hetmana polnego W. X. Litewskiego pisane 1612-1632 roku z autografów biblioteki Cesarskiej w Petersburgu, wyd. Antoni Muchliński, Kraków 1867.

Łukaszewicz J., Dzieje kościołów wyznania helweckiego w Litwie, t. 1-2, Poznań 1842-1843.

Merczyng H., Druga w Polsce egzekucja literacka, „Przegląd Historyczny”, 17 (1913), s. 67-74; Opatrny J. W., [recenzja powyższego] „Kwartalnik Historyczny", 34 (1920), s. 139-148.

Niesiecki K., Herbarz polski, t. 1-10, Lipsk 1839-1846.

Partyka J., Rękopisy dworu szlacheckiego doby staropolskiej, Warszawa 1995.

Pisma polityczne z czasów rokoszu Zebrzydowskiego 1606-1608, wyd. J. Czubek, t. 1-3, Kraków 1916-1918.

Polski Stownik Biograficzny, t. 1-44 - , Warszawa-Kraków 1935 - 2007 -.

Pułaski F., Opis 815 rękopisów Biblioteki Ordynacyi Krasińskich, Warszawa 1915.

Rokosz Zebrzydowskiego. Materiaty historyczne poprzedzone przedmowa i rozprawa pod tytutem Konfederacja i rokosz w dawnem prawie państwowem polskiem, wyd. Aleksander Rembowski, Warszawa 1893, w: Biblioteka Ordynacji Krasińskich. Muzeum Konstantego Świdzińskiego, seria II, t. 9-12, Warszawa 1886-1892.

Radziwiłł A.S., Memoriale rerum gestarum in Polonia 1632-1656, t. 1-5, Wrocław-Warszawa-Kraków 1968-1975.

Roszak S., Archiwa sarmackiej pamięci. Funkcje i znaczenie rękopiśmiennych ksiag silva rerum w kulturze Rzeczypospolitej XVIII wieku, Torun 2004.

Sandius Ch., Bibliotheca antitrinitariorum, Varsoviae 1967.

Siniarska-Czaplicka J., Filigrany papierni położonych na obszarze Rzeczypospolitej Polskiej od poczqtku XVI wieku do połowy XVIII wieku, Wrocław-Warszawa 1969.

Staropolska kultura rękopisu, red. H. Dziechcińska, Warszawa 1990.

Trawicka Z., Działalność polityczna i reformacyjna Piotra Kochlewskiego, „Odrodzenie i Reformacja w Polsce", 8 (1963), s. 125-148.

Trembecki J. T., Wirydarz poetycki, t. 1-2, Lwów 1910-1911.

Uruski S., Rodzina. Herbarz szlachty polskiej, Warszawa 1904-1931; Uzupetnienia, Warszawa 2002.

Urzędnicy dawnej Rzeczypospolitej XII-XVIII wieku. Spisy, red. A. Gąsiorowski, t. 1-11, Wrocław 1985-2002. 
Wallace R., Antitrinitarian Biography, vol. 1-3, London 1950.

Wasilewski T., Ostatni Waza na polskim tronie, Katowice 1984.

Wisner H., Zygmunt III Waza, Wrocław 2006.

\section{SILVA RERUM AUS DEM 17. JAHRHUNDERT IN DEN BESTÄNDEN DER UNIVERSITÄTSBIBLIOTHEK DER KUL}

\section{Zusammenfassung}

Die vorliegende Arbeit betrifft einen in den Manuskriptsammlungen der Universitätsbibliothek der Katholischen Universität Lublin „,Johannes Paul II.” unter der Signaturnummer 2629 des allgemeinen Handschriftenkataloges aufbewahrten Handschriftenkodex aus dem 17. Jahrhundert. Es handelt sich dabei um ein typisches ,silva rerum” aus dem 17. Jahrhundert, das Kopien von Briefen, Reden, Dichtungen und verschiedenartigen historischen Schriftguts enthält, dass mit dem Wirken von Königen, Magnaten und anderen staatlichen Würdenträgern sowie am politischen Leben der Polnischen Adelsrepublik unter der Herrschaft von Zygmunt III., Władysław IV. und Jan Kazimierz aktiven Anteil nehmenden Menschen im Zusammenhang steht. Darüber hinaus finden sich hier auch politische Ansprachen, Akten von Friedensverträgen, zeremonielle und Gelegenheitsreden, das dichterische Schaffen zu bestimmten Anlässen wie Panegyrika, Epitaphien, Klagegesänge, Epigramme, Werke mit politischem und höfischem Charakter, die in polnischer und lateinischer Sprache verfasst wurden. Diese so unterschiedlichen Dokumente sind von fünf Schreibern in einem Zeitraum von einem bis zu mehreren Dutzend Jahren (etwa 1655-1675) kopiert worden. Anfangs wurden sie von einem anonymen arianischen Repräsentanten abgeschrieben, während ein Teil der Dokumente aus dem Archiv der Familie Radziwiłł kopiert wurde - dies betraf das Wirken des litauischen Hetmans Krzysztof Radziwiłł. Eine Hilfe bei der Benutzung dieses Kodex' bietet das Personen- und Ortsverzeichnis. 